\title{
Between Frontline and Parliament: Ukrainian Political Parties and Irregular Armed Groups in 2014-2019
}

\author{
Kostiantyn Fedorenko ${ }^{1,2 *}$ (1) and Andreas Umland ${ }^{3,4 *}$ (D) \\ ${ }^{1}$ Center for East European and International Studies (ZOiS), Berlin, Germany, ${ }^{2}$ Graduate School of Social Sciences, Humboldt \\ University of Berlin, Germany, ${ }^{3}$ Stockholm Centre for Eastern European Studies, Swedish Institute of International Affairs \\ (UI), Sweden and ${ }^{4}$ Department of Political Science, National University of Kyiv-Mohyla Academy, Ukraine \\ *Corresponding authors. Emails: kostiantyn.fedorenko@zois-berlin.de, andreas.umland@ukma.edu.ua
}

\begin{abstract}
The short-lived Ukrainian armed volunteer movement and its interaction with electoral politics, in some regards did, and in other regards, did not fit patterns observed in research into irregular armed groups (IAGs). The brief life span of most Ukrainian IAGs as more or less independent actors, and their swift integration into Ukraine's regular forces during the years 2014-2015, were both unusual. They were also one of the reasons for the relatively low political impact of the IAGs as such - a repercussion that is in contrast to the partly impressive individual political careers of some IAG commanders in 2014-2019. There were various forms of interpenetration of parties with IAGs in post-Euromaidan Ukraine. Certain parties, political activists, and MPs took part in the creation and development of IAGs in 2014. Some - to that point, mostly minor - politicians became soldiers or commanders of IAGs. Subsequently, a number of IAG members transited into the party-political realm, either joining older parties or creating new political organizations.
\end{abstract}

Keywords: Ukraine; post-Soviet; nationalism; political violence

It must be like the Maidan, but with military means. -Arsen Avakov, Minister of Internal Affairs, on the emerging volunteer battalions in 2014

(Hladka et al. 2016, 85)

This article investigates the interaction between, on the one hand, post-Euromaidan Ukraine's main political parties and, on the other, the new irregular armed groups (IAGs) that sprang up in connection with the unfolding war in the Donets' Basin (Donbas). ${ }^{1}$ Having emerged in springautumn 2014, the IAGs largely disappeared as a politically relevant phenomenon by the end of 2015 . We highlight the Ukrainian political parties' role in the formation and absorption of individual and collective actors within the armed volunteer movement emerging in 2014, drawing upon numerous Ukrainian primary sources, media outlets, expert analyses, and political blogs. We also conducted a number of interviews, with some former irregular fighters and contemporary politicians in Kyiv.

As the number of political and military organizations as well as of persons dealt with here is high, the article is more descriptive than analytical. It only scratches the surface of the larger issue of the role of the IAGs for Ukraine's domestic affairs after the Euromaidan. An in-depth investigation into the IAGs' general political relevance during 2014-2015, when they existed as more or less independent units, demands further exploration. This article seeks to provide a descriptive starting

(C) The Author(s), 2021. Published by Cambridge University Press on behalf of Association for the Study of Nationalities. This is an Open Access article, distributed under the terms of the Creative Commons Attribution licence (http://creativecommons.org/licenses/by/4.0/), which permits unrestricted re-use, distribution, and reproduction in any medium, provided the original work is properly cited. 
point for more issue-focused research on the IAGs' political role in early post-Euromaidan history, and their possible impact on decision making within legislative and executive organs on the national and subnational levels. Our article is part of a larger multiauthor, trilateral research project called "Collective Action of Non-State Armed Groups in the Ukrainian Conflict," within which additional articles have been prepared on such issues as, for example, the prehistory, emergence, development, human rights abuses, media representation, and veteran organizations of the IAGs. That is why our below investigation is narrowly focused on only one aspect of the Ukraine's post-Soviet armed volunteer movement and leaves out various other relevant facets of its development dealt with in other articles and chapters forthcoming within this larger project.

The article's primary purpose is to provide a "who's who" of Ukraine's post-Euromaidan IAGs, as well as to explore political parties' personnel interpenetration with the so-called dobrobaty - the commonly used abbreviation for dobrovol'chi batal'ony (volunteer battalions). We describe or elaborate on transitions of IAG members from politics into the dobrobaty and vice versa. While we leave the answer to the question about the overall role of the IAGs in early post-Euromaidan politics open, in the conclusions we make some tentative suggestions on this contentious topic based on our research so far.

For practical and substantive reasons, the article focuses largely on the outgoing 7th Verkhovna Rada (Supreme Council, the parliament of Ukraine) that had been in service until November 27, 2014, as well as the 8th Verkhovna Rada elected on October 25, 2014, and disbanded on August 29,2019 . We also provide below a brief note on IAG representatives in the 9th Verkhovna Rada, which was elected on July 21, 2019, and in which the role of former IAG members decreased sharply. By 2019 the phenomenon of IAGs had almost entirely disappeared from Ukrainian politics, with only some small exceptions mentioned below. An exploration of the fate of former IAG members beyond the exchange of political elites that happened in 2019 would thus be a study of war veterans rather than active or recent fighters, a topic also of interest but not covered here.

\section{From Social Activism to Armed Resistance - and Back}

Ukraine's IAGs emerged in 2014 as partly spontaneously and partly state-guided new paramilitary formations. The seemingly grassroot creation of a whole number of IAGs was, in fact, encouraged, triggered, supported, or even organized by various government officials (Chalavan interview 2017). Soon after the main groups had been established, the Ukrainian state started from approximately late summer 2014 onward - to coopt, integrate, turn, or disperse the new IAGs into regular companies, battalions, regiments, and brigades subordinated to the Ministries of Defense and Interior. As exhilarating as the mushrooming of IAGs was throughout 2014, as astonishing was their nearly complete disappearance as a relatively separate and large phenomenon by 2015.

The prominence that some activists from the armed volunteer movement have gained in early post-Euromaidan Ukrainian national politics is, to a considerable degree, build on the really or allegedly important role that this movement played or is said to have played during the early war period, especially in the volatile months from approximately April to September 2014. In spite of their improvised nature, the first volunteer troops - rather than the regular army that was largely dysfunctional at that time - are credited to have, between late spring and early autumn 2014, saved Eastern Ukraine from being overrun by Russia-directed irregular and, in late August through early September 2014, regular forces.

To be sure, the exact degree of the IAGs' real military relevance is a disputed matter in Ukraine. Yet, a notable impact of the IAGs has been asserted by Ukrainian governmental officials (UNIAN 2017), claimed by representatives of the involved right-wing groups (Pravyy sektor 2017c), and argued by certain experts alike (Francis 2015). There is a widely shared cross-societal perception that the dobrobaty saved Ukraine as a state in mid-2014. 
This real or presumed savior role of the IAGs, after the Euromaidan revolution, elicited then and has continued to elicit since considerable social popularity, public trust, and political support for the initially nonstate fighters in particular, as well as for all soldiers employed within Ukraine's AntiTerrorist Operation Zone (ATO, the official name of the action until 2018) more generally. This was so much so that the majority of competitive parties actively induced former or still active combatants to join their electoral lists for the October 2014 parliamentary and October 2015 local elections. For instance, according to a study by the prominent NGO Committee of Voters of Ukraine, support from and for ATO fighters was one of the most important topics in the electoral campaigns of the parties for the 2015 local elections (VNO "Komitet vybortsiv Ukrainy" 2015).

What follows is a cursory survey of Ukrainian parliamentary and other relevant parties as well as their engagement with the post-Euromaidan IAGs. We briefly introduce the parties and outline their interpenetration and interactions with IAGs. In the conclusions, we extract from this overview some possible implications of the evidence for a broader assessment of the dobrobaty's political role.

\section{Right-Wing Parties and Their Paramilitary Arms}

Although they continue to form a family of relatively minor Ukrainian political groupings, such parties as the Right Sector, Svoboda (Freedom), and National Corps as well as their involvement in the fighting in the Donbas are worth considering here first and foremost (Likhachov 2020). That is because the organizational connection between them and some new IAGs, as sketched out below, was and, partly, still is particularly close. The Right Sector claims to have lost about 60-70 members in combat (Skoropads'kyy interview 2017), Svoboda over 50 members (Syrotiuk 2017), and the Azov Battalion (later: Regiment) 39 members (Zvarych interview 2018).

\section{Pravyy Sektor (Right Sector)}

At its inception as an informal network of Euromaidan activists in late November 2013, the Right Sector consisted of several dozen people, mainly men. The later official press secretary of the Right Sector, Artem Skoropads'kyy (whose real surname is Bychkov), stated that his group had around 70 members on December 1, 2013, mainly coming from an older nationalist paramilitary grouplet named Stepan Bandera All-Ukrainian Organization "Tryzub" (Trident), founded by the microparty Congress of Ukrainian Nationalists in 1993, and led between 2005 and 2013 by Dmytro Yarosh (b. 1971) from the East Ukrainian and largely Russian-speaking Dnipropetrovs'k oblast'. The active core of the Right Sector, during the Euromaidan, consisted of about 150 people (Skoropads'kyy interview 2017).

As the protests unfolded and clashes with law enforcement officers became more frequent and violent, the character of the uprising and outlooks of the protesters became more radical in JanuaryFebruary 2014 (Demokratychni initsiatyvy 2014). Nevertheless, the number of Right Sector members increased only moderately to about 300-500 people toward the end of the uprising (Likhachov 2018). For instance, on January 19, 2014, the Right Sector had, according to Skoropads'kyy (interview 2017), around 400 members. In spring 2014, the number of Right Sector branches throughout Ukraine using, with more or less justification, this new brand name grew, for a while, rapidly in connection with the unfolding conflict in the east. In July 2014, at a rally, Skoropads'kyy declared that the organization was ready to send 5,000 soldiers to the ATO zone (Ukrinform 2014).

As in the case of the non- or less ideological self-defense units on the Euromaidan, the Right Sector's experience and bonding during the Euromaidan protests from December 2013 to February 2014 regained relevance, after the initially civil conflict in Eastern Ukraine in early 2014 had, as a result of Russian mingling, turned into in an armed confrontation in April 2014. The first Right Sector volunteers arrived in the ATO area already in April 2014 and were largely associated with the so-called Dnipro-2 battalion (Viter 2015). This initial group of Right Sector fighters consisted of around 
150 men (Skoropads'kyy interview 2017). The official creation of a separate unit called Dobrovolchyy ukrains'kyy korpus "Pravyy sektor" (Volunteer Ukrainian Corps “Right Sector," DUK) happened on July 17, 2014. The Right Sector's Euromaidan leader Dmytro Yarosh became also the DUK's first military commander. How serious Yarosh's repeated attempts to integrate the DUK into the Ministry of Defense's troops indeed was disputed (Viter 2015). The Corps's fighters, on many occasions, accused the government of malevolence toward their unit (Pravyy sektor 2017c).

At the time when the DUK was formed, Dmytro Yarosh emerged also as the unofficial presidential candidate of the, by then, properly registered new party Right Sector, created on March 22, 2014. Yarosh ran as a formally independent candidate, yet he clearly represented his party. In any case, Yarosh only received $0.7 \%$ in the presidential elections of May 25, 2014, while the Right Sector won 1.8\% during the parliamentary elections on October 25, 2014. The party and Yarosh's program promised to secure that "state status [would] be granted to the Volunteer Ukrainian Corps" (Tsentralna vyborcha komisiia 2014a). Yarosh was the only Right Sector member who entered parliament by virtue of winning a single-member district in the Dnipropetrovs'ka oblast', his native region (Tsentralna vyborcha komisiia 2014c).

There were, early on, allegations that the Right Sector had ties with the infamous oligarchs Dmytro Firtash and Ihor Kolomois'kyy (Naiem 2014). At least concerning Kolomois'kyy, the claim about his initial financial support for the DUK is plausible (Yarosh 2014). Yarosh himself had once acknowledged that Borys Filatov and Hennadiy Korban, Kolomois'kyy's one-time close business partners, in cooperation with the regional Right Sector activist Andriy Denysenko, "made everything possible" to enable their first military operation (Hladka et al. 2016, 282). Filatov, the later mayor of the city of Dnipro (formerly Dnipropetrovs'k), called the Right Sector members "our partners and friends" and announced that they would "support each other" during the 2015 local elections (UKROP 2018). Yet, the Right Sector ultimately decided against participating in those elections (BBC Ukraina 2015b).

In November 2015, Yarosh stepped down as party leader, following an internal conflict with other top party officials. The latter accused him of unwillingness to "return to a revolutionary path" of the party (112.ua 2015). Subsequently, Yarosh and his followers created a new party called Derzhavnyts'ka initsiatyva Yarosha (Statist Initiative of Yarosh). Yarosh also left the DUK, claiming that " $95 \%$ of the volunteers" from the DUK went with him to join his newly formed IAG, Ukrains'ka dobrovol'cha armiia (Ukrainian Volunteer Army, UDA) - a hyperbolic title for a small volunteer unit, to be sure (Yarosh 2016). In his capacity as an MP (Member of Parliament), Yarosh started to push a bill in parliament that would legalize the UDA as a separate unit within Ukraine's army, preserving its internal hierarchy. Though his IAG remained outside Ukrainian regular armed forces, Yarosh stressed that the UDA is "fully subjugated to the [national military] command" and that there are thus "no conflict situations" (Yarosh 2016). Whereas the Right Sector preserved its antisystemic stance, Yarosh's new microparty Statist Initiative moved away from outrightly revolutionary rhetoric.

The parts of the DUK and Right Sector not leaving with Yarosh came under the commands of Andriy Stempits'kyy and Andriy Tarasenko, respectively. These were and are, in contrast to Yarosh, both figures largely unknown to the Ukrainian public (Stempits'kyy 2017). There has not been much official documentation from the DUK on its activities since 2015. Until 2018, the Right Sector's website had hosted only four entries regarding DUK's military record after August 2015 when the respective rubric "Na fronti" (On the Frontlines) had been eliminated as a separate section (Pravyy sektor 2017b).

The Right Sector's website labels the post-Euromaidan Ukrainian leadership an "internal occupant” (Pravyy sektor 2017a). In connection with the split of the organization, Artem Skoropads'kyy (alias Bychkov), the party's Russian-speaking press secretary from Sevastopol, announced that the Right Sector consists of "professional revolutionaries" ready to become "the vanguard of this revolution when it starts" (Facenews 2015). He explained that the Right Sector had "parted with Yarosh" since, unlike him, the party views "parliamentary battles as absolutely 
secondary," "speaks about the need for revolution," and opposes "left-liberal" values (Kuzmenko 2016b). The Right Sector continued to view "lustration of the government, [...] Maidan's demands of just life, [...] Maidan's demands of social standards," as its goals and its fight as a continuation of the Euromaidan.

The post-Euromaidan government was criticized for its alleged "political terror against voluntary battalions, [and] political pressure onto volunteers" (Lashchenko 2015). Among other public activities, the Right Sector appealed, for instance, in 2016 to "all battalions" to protest that year's LGBT pride parade in Kyiv (Lashchenko 2015). Already in 2015, however, the Right Sector had become a distinctly marginal phenomenon in Ukrainian public life. By 2019, the once prominent grouping had all but disappeared from the media space.

\section{Vseukrains'ke ob'ednannia "Svoboda" (All-Ukrainian Union "Freedom")}

The Freedom party, or Svoboda, is the oldest among the more or less significant Ukrainian far-right forces. In 2004, it emerged as a result of a purposeful rebranding of the East Galician ultranationalist fringe group Social-National Party of Ukraine. The Freedom party came to prominence in 2012 when it entered, and formed its own faction in, Ukraine's Verkhovna Rada, after a surprise result of $10.44 \%$ in the proportional part of that year's parliamentary elections (Likhachev 2013). During the Euromaidan, Svoboda's chairman, Oleh Tiahnybok, was one of the most prominent speakers on Kyiv's Independence Square. In 2014, the Freedom Party was, for several months, the minor coalition party of Ukraine's first post-Euromaidan government.

In the October 2014 parliamentary elections, however, Svoboda won only $4.71 \%$ in the proportional part of the voting. Thus, like the Right Sector, it failed to pass the 5\% threshold. While Svoboda managed to send six directly elected deputies to Ukraine's new post-Euromaidan Supreme Council, it lost not only its ministers in government but also could not form a new faction in the 8th Verkhovna Rada. This was a disastrous result after three years of high exposure in Ukrainian mass media, participation in national political processes, and presence in general public life (Shekhovtsov 2014).

As in the case of the Right Sector, supporters of the Svoboda party had taken an active part in the Euromaidan's 2013-2014 peaceful protests and, to a somewhat lesser degree, violent clashes. In contrast to the Right Sector, there had, however, never been a Svoboda-created volunteer battalion not to mention an eponymous battle unit. Instead, Svoboda endorsed the volunteer Sich (Cossack fort) Special Troops Battalion that was created on June 12, 2014, and moved to the Donbas on August 26, 2014 (LB.ua 2014; Tiahnybok 2015).

Viktor Chalavan (interview 2017) referred to the example of Svoboda and its leader Oleh Tiahnybok, in 2014, when reporting that "politicians and civic activists who wanted to help creating these [volunteer] battalions approached us," and that Sich was created as a result of such interaction (Hladka et al. 2016, 92). Above-mentioned Dnipro mayor Filatov claims to have supported Svoboda activists, in their engagement with Sich, with equipment in the early phases of the conflict (Hladka et al. 2016, 201). Nevertheless, Oleksandr Pysarenko, the commander of Sich in 2015, clarified: “We are called 'Svoboda's battalion' because, when we formed, Svoboda helped us a lot [...] not the state gave us [the equipment], Svoboda bought it with their own money [...]. Yet saying that Svoboda equals Sich is wrong. I have never been a Svoboda member" (Sazonov 2015).

By February 2015, the party claimed that approximately 500 members were fighting in the Donbas within the Sich battalion, the Karpats'ka Sich (Carpathian Sich, see below) company, and as individuals in other units including the battalion "Aidar" (Vseukrains'ke ob'ednannia "Svoboda" 2015; Syrotiuk interview 2017). In late 2015, the Sich special troops battalion was refounded as the 4th Company of the Kyiv Regiment - a police special unit subordinated to the Ministry of the Interior. The Sich group on the VKontakte social network indicates that this happened on December 21, 2015 (VKontakte 2015). 
Karpats'ka Sich, a stormtroopers platoon, was created on August 27, 2014. Svoboda announced that it is "not the antitank devices, but the nationalist ideology which makes the 'Carpathians' the most dangerous enemy of the Russian forces" (Svoboda 2015a). The party admitted that the unit consisted of "nationalists who could not get into the National Guard, Sich, or other units because of criminal cases related to [...] the Maidan, downing of Lenin memorials, and other political cases" (Svoboda 2015a). In May 2015, the Carpathian Sich “decided to get legalized” by accepting an offer to become part of the 93rd Separate Mechanized Brigade of the Ukrainian army, while demanding to keep the Carpathian Sich as a separate unit inside the brigade. Initially, the military command agreed. However, in April 2016, the unit was disbanded. Its members either continued service in the brigade within the regular army structure or resigned (Stek 2016).

On February 9, 2015, during a Svoboda congress, a party suborganization called Lehion Svobody, with the double meaning "legion of freedom" and "legion of the Freedom party," was created (Svoboda 2015c). It had about 1,000 members by 2017 (Syrotiuk interview 2017). The Legion's task is to unite party members who were or are fighting in different armed units and to support them, as well as their families, during and after the war. Oleh Kutsyn, then commander of the Carpathian Sich, was appointed the Legion's commander (TSN 2015). Although the Carpathian Sich was dissolved and the Sich battalion integrated into the Ministry of Interior's special forces, the Legion continues to uphold a link between the Svoboda party and radically nationalist soldiers, as documented in numerous entries on its Facebook page (Lehion Svobody n.d.). The party thus retains close and institutionalized ties to members actively serving in Ukraine's armed forces.

Svoboda's 2014 list for the parliamentary elections included, among others, Oleksiy Myrhorods'kyy, a platoon commander within the Ukrainian army's 22nd Mechanized Infantry Battalion (Hromadske.ua 2014). Six Svoboda members won mandates in single-member districts - one in the Kyiv, Poltava, Rivne, and Ternopil's'ka oblast's, and two in the city of Kyiv. Out of these deputies, only one, Oleksandr Marchenko, had participated in the Donbas conflict before the elections, and also served after the elections (Kaliakyna 2015; Svoboda 2015b). In the 2015 local elections, the party was supported by $6.88 \%$ of the voters participating countrywide, thereby increasing somewhat its support in comparison to the 2014 parliamentary elections and obtaining the fifth largest share of votes across Ukraine (Ukrains'ka pravda 2015c; Wikipedia 2018). Svoboda won 125 mandates in regional and local councils, mainly in the Galician Ternopil's'ka, Ivano-Frankivs'ka, and L'vivs'ka oblasts.

Aside from Marchenko, notable Svoboda representatives and 2012-2014 members of parliament who participated, to one degree or another, in the ATO included the (1) former vice-speaker of the Verkhovna Rada, Ruslan Koshulyns'kyy; (2) younger brother of the party leader, Andriy Tiahnybok; (3) former deputy head of the Svoboda parliamentary group Oleksiy Kaida; and (4) head of Svoboda's L'viv branch Markiian Lopachak (Kaliakyna 2015).

Of these, it is known that Andriy Tiahnybok fought in Sich (Nadvirnians'ka Svoboda 2015). The commander of Sich reported that, during his service, the MP adhered properly to military orders (Sazonov 2015). Koshulyns'kyy claimed that he had convinced Kaida and Lopachak to serve in spite of the Ukrainian counterintelligence service's opposition to their service because of the risk that a member of the Verkhovna Rada would end up as a captive in Russia (Kuzmenko 2016a).

Another 2012-2014 Svoboda MP who fought in the Donbas within the Sich battalion was Yuriy Syrotiuk (Nadvirnians'ka Svoboda 2015). Syrotiuk was briefly arrested on September 11, 2015, for participation in mass protests near the Ukrainian parliament that took place on August, 31, 2015 (Ukrains'ka pravda 2015d). Together with other former Svoboda MPs - Eduard Leonov, Ihor Sabii, and Ihor Shvaika - Syrotiuk was suspected of organizing this unrest in front of the Verkhovna Rada (Khomenko 2016). During the clash, a young Sich soldier, Ihor Humeniuk, threw a hand grenade at a group of police officers, resulting in 141 wounded and 3 killed (Ukrains'ka pravda 2015a, 2018). Serhiy Krainiak, a Svoboda activist, was suspected of assisting Humeniuk by setting up a 
smokescreen (20 khvylyn 2015). Arsen Avakov, minister of the interior, accused Svoboda of having consciously planned this attack - an allegation rejected by Svoboda (Ukrains'ka pravda 2018).

\section{Natsional'nyy korpus (National Corps)}

The Azov Battalion was founded as a police special forces battalion on May 5, 2014, and reorganized as a regiment on September 17, 2014 (Kondratenko 2014). On November 11, 2014, the Azov Regiment was made, by an order of the minister of the interior, a part of the National Guard of Ukraine (Ukrains'ka pravda 2014). When asked about the Azov Regiment and the far-right activists serving in the National Guard unit, Arsen Avakov replied: "Is it better if the right radicals are out on the streets, crushing shop windows? Or when they feel responsibility and fight for it for some time?" (Hladka et al. 2016, 431). He and Serhiy Taruta, an oligarch who served as Donets'ka oblast' governor in 2014 and later founded an own party called Osnova (Foundation), had provided the initial funding for the Azov Battalion (Comments.ua 2017). Avakov and Taruta claimed to have provided the material support for its first and legendary military operation, the liberation of Mariupol' from separatists in summer 2014 (Hladka et al. 2016, 356).

While many commentators emphasize the right-wing extremist party as the political background of the Azov Battalion, the Verkhovna Rada deputy and Azov Civil Corps affiliate Oleh Petrenko, once a football fan club activist from Cherkassy and short-term Right Sector member, has stated that $50 \%$ of the early Azov fighters came out of the Ukrainian ultras movement of soccer fans (Petrenko interview 2018). The Tsyvil'nyy korpus "Azov" (Azov Civil Corps) comprises Azov Battalion/Regiment veterans and other nationalist activists, raises financial and material support for the frontlines, recruits fighters for the Azov Regiment, provides, in its own words, "truthful and timely" information about developments in the Donbas, and "created a patriotic environment" via "unification of supporters around the national idea" (Volunteer.org 2018). Azov Battalion's founder and initial commander Andriy Bilets'kyy has described the Azov Civil Corps as "one of the most extended networks of activists in Ukraine" (Lelych 2016).

On October 14, 2016, the Azov Civil Corps, during a meeting, adopted the decision to start a new explicitly political project, the National Corps. Rather than legally creating a new party, two already existing organizations, the Hromadians'kyy rukh "Chesni Spravy" (Civic Movement "Fair Action") and the microparty "Patriot Ukrainy" ("Patriot of Ukraine"), founded in 2005, were merged to form the National Corps (Ukrains'ka pravda 2016a). This followed a long-standing Ukrainian pattern of renaming existing organizations rather than registering new ones when starting novel political projects (Kryvko 2020).

After the Statist Initiative of Yarosh, created as a result of a split within the Right Sector, the National Corps became the second relevant rightist party launched after the start of, and as a more or less direct result of, the Donbas conflict. While representatives of all right-wing parties have attempted to gain political capital by referring to their affiliated military units, the National Corps is a party that dwells even more than its competitors on that particular aspect of its prehistory. Its date of creation, October 14, alluded both to the Orthodox holiday of Pokrova (Protection of the Mother of God) and to the date of the creation of the nationalistic Ukrainian Insurgent Army (UPA) in 1942.

Founder of the Azov battalion Andriy Bilets'kyy became the official leader and main spokesman of the National Corps (Kryvko 2020). Before 2014, he had made racist statement and been known by the nickname "White Leader" (Umland 2016). The Azov battalion and later regiment has been using stylized, coded neo-Nazi symbols such as the Black Sun and Wolf's Hook, yet it publicly denied that they refer to German fascism (Azov.Press 2015). Over the last years, Bilets'kyy has repeatedly denied making, before 2014, racist statements ascribed to him, and even claimed that "if somebody had called me 'White Leader' face-to-face, [that person] would have been beaten." Bilets'kyy still publicly opposes multiculturalism, but he admits that "to be a Ukrainian nationalist today is to believe in values, not racial prejudice," and announced that his new party does not use an 
ethnic criterion to define who can and cannot be part of the Ukrainian nation (Lelych 2016). National Corps activist Stepan Baida admitted that the "Patriot of Ukraine," the Khar'kiv groupuscule out of which the Azov Battalion emerged, had initially been Russian speaking (Baida interview 2017).

In October 2014, Bilets'kyy became an MP from a single-mandate district in the Obolon' district of the city of Kyiv. Initially, he had been scheduled to run as an official Popular Front (see below) candidate. However, an initiative group of political experts sent a letter to Arseniy Yatseniuk, leader of the Popular Front, asking the then prime minister not to nominate Bilets'kyy from that party (Obozrevatel 2014). As a result, Bilets'kyy ran as a formally independent candidate, with only informal support of Yatseniuk's party. His electoral success was a function of his fame as a capable military commander, and agreed-upon representative of the pro-Euromaidan forces, in this SMD (Single Member District). In 2014, his right-wing extremist past was not yet widely known to the Ukrainian public (Verner 2014). Stepan Holovko, spokesman for both the Azov Regiment and earlier the Social-National Assembly, another predecessor organization of the National Corps, in contrast to Bilets'kyy, ran as an official Popular Front candidate in an SMD, yet was not successful (Tsentralna vyborcha komisiia 2014b).

For a while, well-known politician Roman Zvarych served as the formal head of the Azov Civil Corps. Zvarych is an immigrant to Ukraine from the USA, member of the North American Ukrainian diaspora, activist for the Bandera wing of the OUN (Organization of the Ukrainian Nationalists), one-time pupil of the prominent emigree nationalist Yaroslav Stets'ko, deputy of the Verkhovna Rada, and two-time former minister of justice of Ukraine. Zvarych joined the Azov Civil Corps in June 2014 and played, until his departure in autumn 2015, some role in the formation and education of the Azov battalion, regiment, and movement, with regard to both military and political affairs. In the proportional part of the 2014 parliamentary elections, Zvarych had been candidate no. 82 on the list of the Petro Poroshenko Bloc (BPP, see below), but he did not enter parliament, as he was too low on the BPP's table of candidates. Only in April 2018, after he had already left the Azov movement, did he become an MP replacing, until late 2019, BPP deputy Valeriy Patskan, who had been elected head of the Accounting Chamber of Ukraine (Ukrains'ka pravda 2018).

Zvarych has claimed that he was critically involved in organizing combat training for Azov battalion/regiment fighters, by Georgian, American, Lithuanian, and British instructors, and to have advised the Azov movement to refrain from using symbols and ideas that could be linked to Nazism (Zvarych interview 2018). As Zvarych had already left the Azov movement before the National Corps was created, Bilets'kyy denied that Zvarych played any role in the emergence of the new party (Yavir 2016). After his engagement with the Azov movement, Zvarych started to criticize in public the political program of the National Corps for, among other things, its statist economic policy proposals (Zvarych 2016).

\section{Nonparliamentary and Emergent Parties}

\section{Politychna partiia "Hromadians'ka pozytsiia" (Political Party "Civic Position")}

Civic Position describes itself as center-right and is a member of the EU party family Alliance of Liberals and Democrats for Europe (ALDE). Civic Position's leader is former Minister of Defense (2005-2007) and Kyiv-Mohyla Academy political science professor Anatoliy Hrytsenko (b. 1957). Civic Position took part in the 2014 parliamentary elections on a joint list with the pro-Western microparty Demokratychnyy al'ians (Democratic Alliance). The united list won, however, only $3.1 \%$ of the vote, thus falling short of the $5 \%$ barrier and not gaining a faction in the Verkhovna Rada. From the start of the Donbas conflict, Hrytsenko criticized the Ukrainian government for poor decision making and even accused it of "treason" (Dashchuk 2014). 
The only IAG member on the party's electoral list was Oleksandr Kraliuk, head of Civic Position's Volyns'ka oblast' section and an Aidar battalion fighter (Slovo i Dilo 2014). Reportedly, Civic Position, on several occasions, provided material support to IAGs, namely, to the Sviata Mariia (Saint Mary) and Donbas battalions (Hromadians'ka pozytsiia - Lvivs'ka oblast' 2015; Hrytsenko 2014). The leader of the allied Democratic Alliance, Vasyl Hats'ko, declared that he planned to participate in the Donbas conflict. Although he passed military drills with the Kyiv-1 battalion, Hats'ko ultimately did not become a soldier (Rinhis 2016).

\section{Ukrains'ke ob'ednannia patriotiv (Ukrainian Union of Patriots, UkrOP)}

The history of the UkrOP party is closely linked to Ukraine's IAGs of 2014, as several UkrOPrelated politicians, activists, and businesspeople were in one way or another involved with the armed volunteer movement. The party was registered with Ukraine's Ministry of Justice in June 2015. Like Civic Position, it describes itself as "center-right" (Zhytomyr.info 2015). The party's prehistory started with the creation, on December 2, 2014, of the Verkhovna Rada's interfactional UkrOP group that included the independent MPs Borys Filatov, Dmytro Yarosh, Boryslav Bereza, Andriy Bilets'kyy, and Volodymyr Parasiuk (Parasiuk interview 2018). The latter four had formerly been or were then linked to radically nationalist political organizations including the Right Sector, SNA-PU (Social-National Assembly/Patriot of Ukraine), UNA-UNSO (Ukrainian National Assembly - Ukraine National Self-Defense), Congress of Ukrainian Nationalists, and irregular armed groups such as DUK, Azov, and Dnipro-1 (Korrespondent 2015). It might be worth adding that former Right Sector spokesman Boryslav Iukhimovych Bliakher-Bereza is a practicing Jew (Davidzon 2018).

The subsequent creation of a party with the name UkrOP is alleged to have been, above all, a brainchild of above-mentioned oligarch Ihor Kolomois'kyy. Initially, Borys Filatov and Hennadiy Korban, former business partners of Kolomois'kyy, posed as the party's leaders. However, after a conflict with Kolomois'kyy, the latter himself took over the informal leadership of the party (Kachura 2016).

The party name's abbreviation, ukrop, means dill - a picture of which is also in the party's coat of arms. The term ukrop had been initially used by anti-Ukrainian Russian commentators as a derogatory term for Ukrainian soldiers in the Donbas. Yet, the term got soon adopted by Ukrainians as an expression of pride. Military chevrons with a dill symbol, designed by Andriy Ermolenko, became popular among ATO fighters (Dorosh 2015).

In the October-November 2015 local and regional elections, UkrOP was the fourth most successful party and gathered country-wide $7.43 \%$ of the total vote (Ukrains'ka pravda 2015c). The party's nominees for these elections included a number of former IAG members or supporters. Mykola Kolesnyk, UkrOP's candidate for the mayor of Kryvyy Rih, was also a "curator" of the volunteer battalion "Kryvbas" - a name derived from the abbreviation of the unit's home region Kryvorizkyy Iron Ore Basin (Ukrains'ka pravda 2016d). Yevhen Terekhov, UkrOP's candidate for the mayor of Pavlohrad, fought in the 20th Motorized Infantry Battalion of the 93rd Brigade, the former territorial defense battalion "Dnipropetrovs'k," the name of the city now called Dnipro (Ukrains'ka pravda 2015b). Ihor Il'kiv, commander of the Medychna rota imeni Pyrohova (Pyrohov Paramedics Company), became a L'viv Oblast' Council MP (Hladka et al. 2016, 485).

UkrOP maintained relations with the Right Sector via, among others, Dmytro Yarosh's abovementioned personal acquaintance with Korban and Filatov (Obozrevatel 2016). The Jewish-Ukrainian oligarch and UkrOP creator Kolomois'kyy is alleged to have not only supported the creation of the Right Sector's DUK (Bukovskiy 2015). He has reportedly also participated in, that is, cofinanced, the creation of other originally irregular armed groups, including the Dnipro- 1 and Dnipro-2 volunteer battalions, two territorial defense units, and the Donbas battalion, as well as, in their early phases, the Shakhtars'k and Azov battalions (Zhegulev 2014; Rivnens'ki novyny 2014). 
Volodymyr Parasiuk, a prominent Maidan activist who later served in Dnipro-1, says: "I remember who protected Ukraine in 2014. It is unpopular to praise them, but still, it was a team - Kolomois'kyy, Korban, Filatov [, that is, the later UKROP founders], and those around them [...]. All the volunteer battalions formed in Dnipropetrovs'k oblast'; there was a decent [military training] base, shooting ranges; they [at the base] were the first to give out weapons" (Sokyrchuk 2017). Yevhen Hendin, a Ukrainian comedian who became a reputed volunteer, reports that "people were protected when [Kolomois'kyy], [Korban], and Filatov were around." However, "Kolomois'kyy spent little time here. Korban was actually managing" (Hladka et al. 2016, 219).

Filatov reports that, as "[fighters of the first volunteer units] were registered as simple policemen [...], their salaries were laughable, so the financing was backed by the then-governor [of Dnipropetrovs'ka oblast'] Kolomois'kyy, me, and others from our team. From food rations to uniforms, we bought everything with our own money [...]. If the 'Russian World' came here, we would have lost everything. Not only businesses and comfortable life, we would have lost our homeland" (Hladka et al. 2016, 101, 228).

Sviatoslav Oliinyk, Kolomois'kyy's deputy in the oblast' administration, claimed that Kolomois'kyy and Filatov both "understood that this is a temporary engagement [in local governance] [...], but the situation required universal mobilization. Some were mobilized to the battalions, some, like us, to the administration" (Hladka et al. 2016, 202). Yuriy Bereza, Dnipro-1 commander, claimed that since October 2014 Filatov and his team stopped helping the volunteer battalions and that Korban expected to use Dnipro-1 as a unit for private needs. Bereza also stated that, while Kolomois'kyy was indeed involved in the creation of the Dnipro-1 battalion, "[it] never had owners" (Lytvynova 2015; Vlashchenko 2016b).

\section{Parties with Factions in the 2014-2019 Verkhovna Rada}

\section{Vseukrains'ke ob'ednannia "Bat'kivshchyna" (All-Ukrainian Union "Fatherland")}

The most prominent temporary link between the Fatherland party headed by Yuliia Tymoshenko and the volunteer battalions was the one-time prisoner of war Nadiia Savchenko. Though being in Russian captivity, Savchenko led Bat'kivschyna's electoral list for the October 2014 parliamentary elections, in which the party received $5.7 \%$ and thus was able to form a faction. The party more than doubled this result in the 2015 local elections when it received nation-wide 12\% (Ukrains'ka pravda 2015c). Savchenko, a former volunteer for the Aidar battalion (BBC Ukraina 2014), had been captured in Eastern Ukraine and tried in Russia. Until her release in 2016, for a brief period of time she became a national hero in Ukraine.

Savchenko's number one spot on the electoral list was meant to demonstrate Bat'kivshchyna's patriotism and exploited the female prisoner of war's then high popularity. In May 2016, Russia released Savchenko who took up her mandate in the Verkhovna Rada. In December 2016 - or, as her sister claims, already in October that year - Savchenko, however, left the Bat'kivshchyna faction. She participated in controversial unofficial negotiations with the leaders of the unrecognized "people's republics" of Donets'k and Luhans'k without her party's approval (Espreso.tv 2016). Savchenko started her own party, Hromadians'ko-politychna platforma Nadii Savchenko (Nadiia Savchenko's Civic-Political Platform) that, according to a poll, was supported by $0.7 \%$ of the voters in late 2017 (Ukrains'ka pravda 2017a). Later, she was accused of having been involved in a curious terrorist plot to blow up Ukraine's parliament and was under arrest for a while.

The number three on Bat'kivshchyna's electoral list for the 2014 parliamentary elections, Ihor Lutsenko, a political activist unrelated to Ukraine's attorney general of that time, was temporarily also an ATO fighter within the Azov battalion (Lutsenko 2014). In 2015, Volodymyr Katruk, commander of the volunteer battalion "Ternopil'," participated in the elections to the Ternopil' city council on the list of Bat'kivshchyna (Halas 2015). Semen Salatenko, a former Dnipro-1 battalion 
fighter, served for a while as head of the Sums'ka Oblast' Council, representing Bat'kivshchyna, yet he resigned after a scandal and returned to the ATO zone (Skorokhod 2017).

On April 30, 2014, Tymoshenko had called for citizens of Ukraine to participate in the "protection of the Ukrainian borders against the Russian aggressor" by way of creating and joining territorial defense battalions. In May 2014, answering this call, two such battalions - Bat'kivshchyna and Rukh Oporu (Resistance Movement) - were created, with the support from the party, in the Kirovohrads'ka oblast'. While being volunteer battalions, they were, from the start of their activities, fully subordinated to the Ministry of Defense and thus not classical IAGs. In November 2014, these two battalions, together with another territorial defense battalion from Kirovohrads'ka oblast', were merged into one unit (Zhyrokhov 2016). They have on several occasions received material support from Tymoshenko's party (Tymoshenko 2018).

\section{Radykal'na partiia Oleha Liashka (Oleh Liashko's Radical Party)}

The flamboyant nationalist and populist Oleh Liashko played, throughout 2014, a special role within the armed volunteer movement. He was the Ukrainian veteran politician who linked himself most demonstratively to the emerging IAGs. Presenting himself as a "people's candidate," Liashko sought, in summer 2014, to create the public impression that he was himself a frontline fighter for Ukrainian independence. However, it was soon found out that video scenes showing his participation in combat and his interrogations of prisoners of war were staged (TSN 2014). He then stopped claiming personal participation in the war. His party nevertheless won $7.4 \%$ in the October 2014 parliamentary elections and $6.7 \%$ of the total vote across Ukraine in the 2015 local elections, sharing the fifth-best result with Svoboda (Ukrains'ka pravda 2015c).

In summer 2014, Liashko cooperated closely with the newly created and then relatively small Azov battalion. The Azov Civic Corps site even maintains that Liashko was one of the battalion's creators (Volunteer.org 2014). In an article for the website of the Azov battalion, the famous rightwing journalist Olena Bilozers'ka acknowledged Liashko's role, reporting that "the Patriot of Ukraine and the Social-National Assembly are the backbone of Azov, but not all battalion fighters are nationalist. Moderates [in the battalion] do not have problems with people who have tattoos of runes or inscriptions such as '[I am a] 100\% racist.' And, if someone does have such problems, he would not admit that, since in Azov, not least thanks to Oleh Liashko, it is possible to fight. Not all units are so lucky" (Volunteer.org 2014).

Liashko is also alleged to have helped with the creation of the battalion "Ukraina" that was later renamed Shakhtars'k (Buniak 2014). However, already before the October 2014 general elections, Liashko appeared to have lost interest in, or the support of, the Azov battalion/regiment. The Shakhtars'k battalion was disbanded in September 2014 (Vasylchenko 2014). Still, the Radical Party made heavy use of representatives of various IAGs in its public positioning for the October 2014 parliamentary elections and also included some further activists in one way or another linked to the armed volunteer movement.

The Radical Party's list for the proportional part of the 2014 parliamentary elections included, among others:

- Serhiy Mel'nychuk, former commander of the Aidar battalion, on position 3

- Artem Vitko, commander of the Luhans'k-1 battalion, on list position 7

- Ihor Mosiichuk, formerly an SNA-PU activist and Azov battalion press secretary, on position $9^{2}$

- Andriy Artemenko, affiliated with the Right Sector, on position number 13

- Oksana Korchyns'ka, wife of Dmytro Korchyns'kyy, head of the ultra-nationalist Bratstvo (Brotherhood) Party and St. Mary Battalion, on position 19

- Dmytro Lin'ko, linked to Bratstvo and the St. Mary Battalion, as well as, formerly, to the Azov and Shakhtars'k battalions, on position 20 
- Ihor Kryvoruchko, a veteran of the SNA-PU and an Azov Regiment company commander, on position 23 (Chernyshev 2014a; Mamon 2015; Hladka et al. 2016, 360-361; Gonta 2015). ${ }^{3}$

The most prominent IAG representative on the Radical Party's list, Mel'nychuk, later left the party after a public conflict with Liashko. On December 8, 2016, Yuliia Tolopa, a former Russian citizen and female Aidar battalion fighter who had fled to Ukraine from Russia, attacked Liashko in the building of the Ukrainian parliament and spilt tomato juice over him. Tolopa had previously asked Liashko and Mosiichuk several times to help her obtain Ukrainian citizenship, but she did not manage to receive it. Liashko accused Mel'nychuk, in response to Tolopa's attack, of organizing this provocation (112.ua 2016a). ${ }^{4}$

Liashko also alleged that he had to include Mel'nychuk into the party's 2014 ballot under financial pressure from the oligarch and former head of Yanukovych's presidential administration Serhiy L'ovochkin. Liashko claimed that the armed volunteers loyal to Mel'nychuk were functioning as guards to L'ovochkin's private property. He reported that Mel'nychuk had to be expelled from the party because of an earlier protest action when Mel'nychuk, together with other Aidar battalion members, tried to set the Ministry of Defense on fire. Mel'nychuk responded that the Aidar fighters had to do so to remind the government who had brought them to power. He also accused Liashko of political corruption (Pidvezianyy and Peshko 2016; BBC Ukraina 2015a).

\section{Ob’ednannia "Samopomich" (Association "Self-Help")}

Samopomich grew out of the Euromaidan movement, promised during the election campaign of 2014 to create a technocratic government (24 kanal 2014), won 11\% in the October 2014 elections, and attracted, in particular, many middle-class voters (Butkevych 2016). In the local elections of October 2015, the party won $6.3 \%$ of the vote and finished seventh, with its support mostly concentrated in Western Ukraine (Ukrains'ka pravda 2015c). ${ }^{5}$ While being closely linked to many activists who went to the ATO, Samopomich did, unlike the Radical Party or Bat'kivshchyna, not found or cofound any IAGs officially tied to the party. The party's Kharkiv branch only provided some material support to the Kharkiv-1 volunteer police battalion, which participated in the ATO (Samopomich Kharkiv 2014).

In mid-2014, Samopomich also started to develop a special partnership with the battalion "Donbas." This expressed itself, above all, by the fact that some of Donbas battalion's representatives became Samopomich's list and direct candidates for the 2014 parliamentary elections. They included Donbas's Commander Semen Semenchenko (real name: Kostiantyn Hryshyn) as number two and Pavlo Kishkar, head of the battalion's so-called "information war group" as number eleven of the party list (Liga.Novosty 2014). Semenchenko reported that "both [the contact with] Samopomich and the decision to run emerged two months before the elections" (Vlashchenko 2016a).

While - unlike the Azov battalion or DUK - not having an ultranationalist background, the Donbas battalion was one of the more radical and politically engaged IAGs already in 2014 . On November 3, 2014, a Donbas battalion fighter, for instance, declared on air that, should Ukraine cede "even a kilometer" of its land to the so-called Donetsk and Lugansk People's Republics, Poroshenko [would] be overthrown" (Press Post 2014). Semenchenko, one of the most shimmering of Ukraine's new politicians coming out of the IAGs, had once served with the Soviet Black Sea Fleet in Sevastopol (Semenchenko 2018). According to Vitaliy Atanasov, "Semenchenko has been accused of making risky decisions at the front, illegal adoption of a military rank, and attempting to hide his past [...]. Moreover, [in 2015], video recordings emerged showing Semenchenko inside the Donets'k regional administration building during its occupation in March 2014" (Atanasov 2016). Nevertheless, Semenchenko was, in late April 2014, successful in summoning his Donbas volunteer battalion via a simple Facebook announcement that had allegedly assembled around 
600 potential fighters by April 25, 2014 (Semenchenko 2018). He settled in Dnipropetrovs'k (later renamed to Dnipro), where the Donbas battalion established its base.

Having become, by late 2014, a temporarily prolific politician, Semenchenko was involved in a dubious episode in Kryvyy Rih. A popular local Samopomich activist, Yuriy Myloboh, narrowly lost to Yuriy Vilkul, the father of a prominent pro-Russian Opposition Bloc politician and partner of Ukraine's richest oligarch Rinat Akhmetov, in the second round of the mayoral elections of Kryvyy Rih, in November 2015. However, parliament ordered, because of irregularities, a rerun of this election in 2016. Instead of Myloboh, the local party organization nominated as candidate for mayor Semenchenko who too lost the race to Vilkul. That led to - perhaps, unfounded - accusations of a dohovorniak (shady deal, fixed game), between the local Samopomich and Opposition Bloc branches. ${ }^{6}$ There was a suspicion that the Kryvyy Rih branch of the pro-Western Samopomich party had purposefully given up the mayor position to a successor organization of Yanukovych's Party of Regions (Liga.Novosty 2014).

On January 18, 2016, Donbas battalion veterans rallied near the presidential administration, demanding to investigate why the 2014 Ilovais' $k$ battle had been lost and to prosecute those guilty of the defeat (Liga.Novosty 2014). On May 3, 2016, Semenchenko coordinated, in Kyiv, a protest meeting against a disbanding of the infamous Tornado battalion accused of marauding. On that day, there was a court hearing concerning eight representatives of the Tornado IAG who had been detained on suspicion of committing violent crimes, including torture (Korrespondent 2016b). During 2017, Semenchenko, together with Yehor Sobolev, coordinated an unsanctioned economic blockade of the occupied territories of the Donbas and an anti-Poroshenko protest camp under the parliament (Vovnyanko 2017; Ukrains'ka pravda 2017b).

Semenchenko's actions were indicators of growing division between Ukraine's postEuromaidan regime, on the one side, and the volunteer movement, including some remaining IAGs and the volunteer units integrated into the regular armed forces, on the other. In the early days, the postrevolutionary political regime and IAGs had been a largely united force. For instance, on July 4,2014, when Poroshenko was giving a speech to parliament, the building was guarded by the members of the Donbas battalion. As the then just emerging IAGs' commander Semenchenko explained, "information regarding possible terror attacks was received, [and thus] the sending of some of [the battalion's] companies to the East was temporarily halted [in order to provide protection in Kyiv - K.F./A.U.]" (Expres 2014). By September 2017, Semenchenko's Donbas battalion veterans were, in contrast, protecting Poroshenko's rival Mikheil Saakashvili when he, despite not being legally entitled to do so, entered Ukraine (ZIK 2017).

\section{Blok Petra Poroshenka "Solidarnist" (Petro Poroshenko Bloc "Solidarity," BPP)}

President Poroshenko's BPP party list for the proportional part of the October 2014 elections did not include any official representatives of IAGs and not even any other recent combatants. Poroshenko's Bloc was thus one of only two major parliamentary parties - the other being the Opposition Bloc - that did not put serving or demobilized candidates on its national list (Shuklinov 2014). This may have been due to Poroshenko's intention to position his Bloc as a catchall party. The purpose of not featuring ATO participants prominently was, perhaps, to avoid controversy over the war record of the fighters and not to alienate Russophile voters in Ukraine's east and south. Also, as indicated above, some of the most prominent volunteer battalions had ties to the oligarch Ihor Kolomois'kyy who later came out as a fierce opponent of Ukraine's fifth popularly elected president. Poroshenko may have, already in 2014, seen his then ally Kolomois'kyy as a potential rival for political influence in Ukraine and thus may have not wanted to bring IAG members linked to the oligarch into parliament.

At the same time, there were several members of the armed and ATO-related civil volunteer movement who were elected, with the help of the Poroshenko Bloc, in single-member districts (SMDs). Thus, Oleh Petrenko - a former football fan club and temporary Right Sector activist in 
spring 2014 - was elected in an SMD, in his native Cherkas'ka oblast' (Petrenko 2018). During the Euromaidan, he had been involved in street fighting. In June 2014, Petrenko joined the Azov Civil Corps and subsequently became close to Bilets'kyy. In the Verkhovna Rada, he became a member of the Poroshenko Bloc's parliamentary faction, while preserving his link to the Azov Regiment and entering the National Corps (Petrenko 2018).

Poroshenko's son, Oleksiy, claimed to have fought in the ATO as a volunteer, albeit under a pseudonym, for purposes of security, and was elected in a single-member district (S'ohodni 2014a). Andriy Denysenko, who created the Dnipro-1 battalion, was also officially elected as an MP from the BPP in the Dnipropetrovs'ka oblast' (Dzerkalo tyzhnia 2015). He later joined the UkrOP group in parliament but left this group too in 2016 (Ukrains'ka pravda 2016b). Oleksandr Tret'iakov, one of the most influential MPs in the BPP faction, claims to have provided support to the Azov battalion, the Right Sector's DUK, and three territorial units in 2014 (Shestopal and Horbach 2014).

Despite accusations among Ukraine's IAGs that he was "destroying" the volunteer movement in Ukraine, Poroshenko has, on numerous occasions, demonstratively supported and shielded the volunteer battalions (Ruzhyns'kyy 2014; Informator 2016). At the celebration of the second anniversary of the formation of the National Guard in the Ministry of Interior in 2016, Poroshenko, for instance, explicitly praised the first volunteer unit formed in 2014 in Ukraine, the Kulchyts'kyy battalion (112.ua 2016b). During a number of scandals in connection with IAGs, Poroshenko interfered on behalf of the volunteer units and, for instance, stopped the imminent disbanding of the Aidar battalion in June 2014 (S'ohodni 2014b). In other cases, such as when the Tornado battalion was accused of violent crimes, he kept silence.

About two years after the victory of the Euromaidan, if not before, relations between the president and volunteers became increasingly sour. On May 20, 2016, for instance, Poroshenko accused fighters of the Azov battalion, who had burned tires and exploded petards during a march in Kyiv, of creating "a picture [beneficial] for the Russian TV." The Azov regiment veterans' protest was targeted against possible elections in the Donbas after Poroshenko had declared his adherence to the Minsk Agreements, which prescribe such elections (Korrespondent 2016a). The following years, many volunteer units and their veteran organizations turned against Poroshenko.

\section{Narodnyy front (Popular Front)}

On April 7, 2014, Oleksandr Turchynov, the then-acting president of Ukraine, de facto started the ATO by declaring that antiterrorist methods should be employed against pro-Russian separatists who were then capturing, with Moscow's encouragement and help, administrative buildings in Eastern Ukraine. On April 13, 2014, the National Defense and Security Council of Ukraine passed a decision "on immediate measures with regard to curbing the terrorist threat and maintaining the territorial integrity of Ukraine," which constituted the de jure start of the ATO (Kharkiv Human Rights Protection Group 2014). During the following months, on numerous occasions, Turchynov spoke highly of the volunteer battalions (Tsenzor.NET 2017). This previewed the soon to be established particularly close connection between Turchynov's new party, the Popular Front, and Ukraine's armed forces - in particular, the emerging IAGs.

Although the Popular Front became a functioning organization only in September 2014, that is, less than two months before the parliamentary elections of October 25, 2014, it won the proportional part of these elections with $22.2 \%$ of the turnout. Somewhat paradoxically, the Popular Front did not, however, even run in the 2015 local elections, as its support had plummeted by then. Since Arseniy Yatseniuk, the party's public leader, was Ukraine's prime minister during the deep economic crisis years of 2014-2016, the voters evidently deemed the party responsible for the socioeconomic collapse of that time.

The Popular Front's October 2014 electoral victory was also surprising in view of the fact that the Front's emergence had been somewhat accidental. The party ran only because its leaders, Turchynov and Yatseniuk, had not been able, in summer 2014, to agree with their then allies, Yuliia 
Tymoshenko and Petro Poroshenko, on their and their affiliates' positions on the electoral lists of Fatherland and Solidarity, for the upcoming parliamentary elections. Thus, Turchynov and Yatseniuk founded a new party with a demonstratively militaristic but not ultranationalist selfimage, and they focused on issues of national defense as well as state security. The new party quickly carved out a particular nonextremist nationalist political niche of its own. One of the corollaries of its campaign was establishing close links to the armed forces and, in particular, to the recently emerged IAGs (Chernyshev 2014b).

A number of prominent participants of the ATO or figures publicly linked to the armed volunteer movement were placed on high positions of the Popular Front's party list for the proportional part of the elections. Other IAG members were elected in single-member districts with the help of the Popular Front. The most prominent list candidates among the party's top 25 positions included:

- Andriy Parubiy, former head of the National Security and Defense Council, on position 4

- Andriy Teteruk, the commander of the Myrotvorets' (Peacekeeper) battalion, on position 5

- Arsen Avakov, minister of internal affairs, on position 6

- Yuriy Bereza, then commander of the Dnipro-1 battalion, on position 10

- Anton Herashchenko, the Interior Ministry's "coordinator of the volunteer battalions," on position 21 (Chernyshev 2014c). ${ }^{7}$

Andriy Parubiy, briefly head of the National Security and Defense Council in 2014 and speaker of the Ukrainian parliament in 2016-2019, is among the most prominent politicians linked to the IAGs. Parubiy had been the commander of the Euromaidan's Samooborona (self-defense), that is, the numerous so-called sotni (hundreds) that protected the protesters during the Revolution of Dignity of 2013-2014. He stood thus at the origins of those IAGs that were created out of Samoborona sotni, and he was personally acquainted with many of the IAG commanders.

In the early 1990s, Parubiy had been one of the creators of the above-mentioned Social-National Party of Ukraine in Galicia, the predecessor organization of Svoboda (BBC Ukraina 2016). Parubiy, however, strayed away from Svoboda in early 2005 and joined instead Viktor Yushchenko's moderately nationalist Nasha Ukraina (Our Ukraine) party (BBC Ukraina 2016). During the 2004 Orange Revolution, he had been one of the protests' key organizers and the "commandant" of the Ukrainian House - a prominent location in the Kyiv city center controlled by the protesters and the headquarters of the electoral uprising.

Against the background of his 2004 experience, Parubiy became in late 2013 also the "commandant" of the Euromaidan protesting camp and came to play "one of the key functions in the organizational structure of Euromaidan" (BBC Ukraina 2016). After the protesters' victory, he coinitiated the incorporation of the Euromaidan's self-defense units into the emerging National Guard of the Ministry of Interior as volunteer units (Depo.ua 2017). In spring 2014, Parubiy ordered the Euromaidan's self-defense units to capture the buildings of local authorities in the north of the Luhans'ka oblast' in order to prevent them from falling into the hands of Russian-led separatists (BBC Ukraina 2016).

As minister of the interior since late February 2014, Arsen Avakov also played a crucial role in the formation of the volunteer battalions, and he later managed to induce several of them to merge into the National Guard. Anton Herashchenko, an advisor to Avakov, was intimately involved in the communication between the ministry of the interior and emerging IAGs. He, for instance, supported the creation and activities of the Shakhtars'k battalion, according to Andriy Filonenko, its commander. Herashchenko explained that, before the separatist combatants started to operate heavy weapons, the task of the new volunteer battalions had been to "bring order" to the settlements "liberated from the terrorists" (Karpiak 2014).

The reserve colonel and former United Nations peacekeeper Andriy Teteruk was, in spring 2014, asked by the ministry of the interior to form a unit out of former Ukrainian participants in 
peacekeeping operations. Teteruk reported that interim President Turchynov and Interior Minister Avakov took a special interest in the creation of the Myrotvorets' battalion (later, regiment) out of military professionals (Teteruk interview 2018). Their close contact since spring 2014 apparently facilitated Teteruk's inclusion into the Popular Front's electoral list a few months later. Teteruk emphasized that his battalion was an explicitly neutral fighting unit with no political ideology (Teteruk interview 2018).

According to Viktor Chalavan (interview 2017), who coordinated the creation of many dobrobaty, the Kyiv-1, Dnipro-1, and Zoloti Vorota (Golden Gate) IAGs were among the first such units. During their formation, often more or less prominent personalities played some role, among them above-mentioned Yuriy Bereza and Yevhen Deidei, another later Popular Front MP (Hladka et al. 2016, 88). They, together with Teteruk, were considered to be in Avakov's informal influence group within the Popular Front (Ukrains'ka pravda 2016c). Bereza has, however, denied that his Dnipro-1 battalion is affiliated to Avakov or anyone else except "the people" (Hladka et al. 2016, 194). Teteruk has claimed that, after his election to the Rada, he only participates in honorary events of the Myrotvorets' regiment and keeps only personal (and no political) contacts with fighters he served with (Zheliznyak 2017).

There were more 2014-2019 Popular Front MPs coming out of the armed volunteer movement. Mykhailo Havryliuk, a Maidan hero with later links to the Zoloti Vorota (Golden Gate) unit, won in October 2014 an SMD seat in the Rada, with the support of the Popular Front (Antykor 2015). As mentioned, Andriy Bilets'kyy, the Azov battalion's creator and first commander, ran in Kyiv with unofficial support from the Popular Front. Mykhailo Bodnar, elected in the L'vivs'ka oblast' in October 2014, had fought in the Kulchyts'kyy battalion (Narodnyy front 2018). Millionaire V'iacheslav Konstantinovs'kyy had volunteered as a fighter in the ATO, within the rapid response unit "Kyiv-tsentr" of the Kyiv-1 battalion. Konstantinovs'kyy became famous after he had sold his Rolls Royce car and donated the UAH 2.5 million he had received for it for medical treatment of soldiers injured in the ATO and for purchasing equipment for units fighting in the Donbas (Obozrevatel 2016).

West Ukrainian Popular Front MP Ihor Lapin, formerly a Maidan activist, had served, before his election, as the commander of the 2nd Company of the Aidar battalion and received several awards for his service. After being elected to the Verkhovna Rada, as per Lapin's official biography, he "visits [the] ATO [zone] to help our fighters, share skills and experience of conducting [military] operations" (Lapin 2018b). Lapin was subsequently accused of (or defamed for alleged) corruption and of forging his military biography by an investigative journalist (Volyns'ki novyny 2017). The latter allegation seemed, in view of ample video documentation of Lapin's military service, however, misleading (Lapin interview 2018a).

\section{IAG Representatives in the 2019 Parliamentary Elections}

Already by the end of 2015, almost all dobrobaty that had previously been irregular or semiregular units had either dissolved or entered the regular troops of the Ministries of Defense and Interior. In 2018, journalists reported that approximately 200 nonenlisted fighters were left in Ukraine, primarily related to the above-mentioned minor IAGs that had come out of the Right Sector, that is, the hyperbolically named "corps" DUK and "army" UDA (Burdyha 2018). The trend for the parties to include former volunteer battalion representatives into their electoral lists greatly diminished in the July 2019 parliamentary elections in comparison to those of October 2014.

For instance, Sluha narodu (Servant of the People) - the party of Volodymyr Zelens'kyy who had become president of Ukraine in spring 2019 - included only one former voluntary fighter, Yehor Chernev, in its electoral list. Chernev had served as a National Guard volunteer in 2014-2015 (Berdyns'kykh 2020). Sluha narodu won in the July 2019 Verkhovna Rada elections 254 out of 424 seats, including 130 out of 199 seats distributed via single-member districts (Tsentralna vyborcha komisiia 2019b). ${ }^{8}$ Only two of the parliamentarians elected in SMDs had served in 
former IAGs: Mykhailo Bondar had been a commander in the Kul'chyts'kyy National Guard Battalion (Slovo i Dilo 2020), and Andriy Bohdanets' had served in the above-mentioned Sich battalion that had relations to the Svoboda party (Chesno 2020).

Via Evropeis'ka solidarnist' (European Solidarity, ES), Poroshenko's rebranded party, Yana Zinkevych became an MP in 2019. Zinkevych had earlier created and commanded the medical battalion "Hospital'iery" (Hospitallers), a unit that specialized in evacuating wounded soldiers and providing first aid (Odintsova 2019). Furthermore, the ES brought above-introduced Andriy Parubiy back into parliament. Holos (Voice), a new pro-Western party led in 2019-2020 by the famous singer Sviatoslav Vakarchuk, had the theatre actor and director Andriy Sharas'kin, a onetime fighter of the Right Sector's DUK and later coleader of Yarosh's Statist Initiative, on the 20th position of its electoral list (Ukrains'ka pravda 2019). Yet, Holos managed to get only the first 19 candidates on its party list into parliament. Sharas'kin thus did not immediately become an MP in November 2019 but only in November 2020 after Vakarchuk had left politics (Verkhovna Rada Ukrainy 2020).

Several MPs of the 9th Verkhovna Rada were either fighters of regular units or, in one way or another, linked to the Ukrainian army. Yet, no further MPs, apart from those mentioned, who were elected either via party lists or as official party representatives in SMDs had served in semi- or irregular units. To be sure, Svoboda's united far-right list for the elections notably included such prominent, above-mentioned former fighters as Dmytro Yarosh, Andriy Bilets'kyy, and Andriy Tarasenko (Tsentralna vyborcha komisiia 2019a). Yet, the attempt of the Ukrainian far right to run, as a joint bloc, together with prolific former ATO soldiers did not succeed in the 2019 parliamentary elections. The united list of most of Ukraine's radical nationalist parties failed to pass the 5\% threshold, scoring only $2.15 \%$ of the proportional vote (Tsentralna vyborcha komisiia 2019c).

Against the background of Svoboda's example and in view of the above, including representatives of the IAGs in party lists was, so it appears, an only temporarily profitable strategy in Ukraine's post-Euromaidan electoral politics. It was a political fashion characteristic of the especially dramatic year 2014 when the Revolution of Dignity triumphed, Ukraine lost control over Crimea, and Russia started a pseudo - civil war in the Ukrainian part of the Donets' Basin. The peculiar context facilitating IAG members' transition into politics after the Euromaidan had evaporated by the time of the following parliamentary elections in mid-2019. Without a significant increase in the intensity of the conflict in the Donbas, one can hypothesize, a repetition of the 2014 wave of entries of IAG fighters into Ukrainian high politics appears as unlikely.

\section{Conclusions}

Our survey has listed various forms of interaction, intersection, and interpenetration between parties and IAGs in post - Euromaidan Ukraine. Several parties, party leaders, and MPs took an active part in the creation and development of IAGs in 2014. Some - to that point, mostly minor politicians became soldiers or commanders of IAGs. Later on, a number of formerly nonpolitical or hitherto politically marginal IAG members transited into the national party-political realm - either by way of joining older parties or through creation of new political organizations. We have briefly dealt with most of this back and forth between Ukrainian parties and IAGs, as well as their successor units, within Ukraine's regular armed forces.

By late 2014, a number of IAG commanders had become members of Ukraine's post Euromaidan national parliament. Some of them had been active in politics already before their engagement in the armed volunteer movement. Yet, most made the jump into the Verkhovna Rada via, in light of, and often with explicit reference to, their service within an IAG. Certain IAG members - for example, the above-mentioned Azov battalion affiliates Kryvoruchko and Holovko tried but did not manage to enter the national parliament as deputies. Still other IAG representatives were elected to regional and local representative and executive organs, as a result of their participation in the 2015 oblast' (region), rayon (district), municipal, and hromada (community) 
elections - a phenomenon we did not cover here comprehensively and worthy of a separate exploration.

A number of IAG members made quick transitions from and to national-level politics in postrevolutionary Ukraine. The immediate biographical background of the IAG representatives entering the Verkhovna Rada in October 2014 played a role in their public profile, popularity, and rise. A more complicated issue to which our paper contributes, but which is not resolved here conclusively, is whether the irregular Ukrainian armed formations exerted any notable domestic political impact during 2014-2015 beyond matters directly related to Ukraine's confrontation with Russia. From what we have documented above, it does not appear that the IAGs were a directly usable political resource for new people's deputies coming out of the armed volunteer movement, or for the parties that had developed close links to a volunteer fighting unit. At minimum, the more alarmist post-Euromaidan warnings about a destabilizing rise of the IAGs and their successor organizations - a role comparable to, for instance, that of the infamous post-World War I Freikorps (Free Corps) in Weimar Germany - proved to be overdrawn (Hahn 2015; Aliyev 2018).

A number of graduates of the armed volunteer movement, to be sure, did not hide their political ambitions, made impressive political careers, and espoused more or less radical views. Some came to influence, as individuals, Ukrainian political affairs in one way or another. However, within this project we did not find significant evidence that IAGs, or their successor units within Ukraine's regular forces have - as fighting units equipped with firearms and partly even with heavy weapons shaped to notable degrees Kyiv's domestic policies, the Ukrainian polity, or national-level politics of post-Euromaidan Ukraine. The exception were certain decisions by Kyiv related to its conflict with Moscow in which the IAGs themselves participated as fighting (and not political) units - a topic demanding separate scrutiny. Neither in the period 2014-2015, when the IAGs had been more or less independent, nor afterward, when most of them were integrated into the troops of the Ministries of Interior or Defense, did the dobrobaty as armed groups seem to have exerted much impact, on the president's, cabinet's, or parliament's decision making with regard to - narrowly defined - internal affairs. This only excluded those relevant governmental decisions that were related to the interstate confrontation, on Crimea and in the Donbas, with Russia.

Instead, it appears that both the IAGs' disbandment or transformation into regular units, and the subsequent transition of a number of well-known IAG leaders to parliamentary politics, quickly diluted the disruptive political potential that the IAGs might have had in circa mid-and late 2014. As had earlier been observed in comparative research unrelated to Ukraine, an engagement both of individual irregular fighters and of entire paramilitary groups in electoral politics can lead to their pacification. In such cases, the IAGs and their members turn into increasingly ordinary political actors who neither use nor threaten to employ their access to weapons for political purposes (Ahram 2011; Acosta 2014). Such a transformation may have also happened in post-Euromaidan Ukraine.

A convincing verification or falsification of this preliminary inference emerging from the above outline, concerning the pacifying effect of Ukrainian IAG members' transition to party-political affairs, demands further investigation. Such research would concern not only personnel interpenetration of Ukrainian parties with IAGs, but also other forms of interaction of IAGs with Ukraine's legislature and executive, especially during the period 2014-2015. Such future analyses can, moreover, more deeply advance an integration of the study of post-Euromaidan Ukraine's dobrobaty into the international comparative study of IAGs (Ahram 2011; Acosta 2014).

Financial Support. The article is a result of the project "Collective Action of Non-State Armed Groups in the Ukrainian Conflict: A Comparison of Pro-Russian and Ukrainian Non-state Armed Groups,” led by Professor Andreas HeinemannGrüder (University of Bonn), funded by the Volkswagen Foundation in Germany, and jointly implemented by the Bonn International Conversion Center (BICC) and Institute for Euro-Atlantic Cooperation in Kyiv (IEAC). See: app.dimensions.ai/ details/grant/grant.4974241. The article has also benefited from support by "Accommodation of Regional Diversity in Ukraine (ARDU): A research project funded by the Research Council of Norway (NORRUSS Plus Programme).” See: blogg.hioa.no/ ardu/category/about-the-project/. 


\section{Notes}

1 On recent developments in Ukraine's party-political and national electoral landscape, see Fedorenko, Rybiy, and Umland (2016).

2 Mosiichuk either left voluntarily or was kicked out of the Azov battalion, in summer 2014. He was later accused of corruption and had his parliamentary immunity removed, although the court subsequently ruled that this decision was illegal (Radio Svoboda 2016).

3 Kryvoruchko did not, however, become an MP but became a parliamentary assistant to Lin'ko (Gonta 2015).

4 Further on Tolopa, see Coynash (2017).

5 According to the Kyiv International Institute of Sociology and Democratic Initiatives Foundation, Samopomich's rating, as of December 2017, was at 7.0-7.4\% (KMIS 2017; Demokratychni initsiatyvy 2017).

6 The problem, though, may have been also Myloboh himself who, for unknown reasons, decided not to run in the repeat elections where he had to be replaced, and the choice fell on Semenchenko. There may have been simply no fully adequate Samopomich alternative for Mylobloh available.

7 The MP Kostiantyn Mateichenko, elected on the Popular Front list's number 26 to the Verkhovna Rada in 2014, was commander of the battalion "Artemovs'k" (Chalavan interview 2017).

8 The constitutional size of the Ukrainian parliament is 450 MPs. However, as single-member district elections in Crimea and the uncontrolled parts of Donbas are impossible, 26 seats are left empty.

\section{References}

20 khvylyn. 2015. "Shche odnoho kam'ianchanyna Serhiia Krainiaka pidozriuiut v orhanizatsii biini pid Radoiu: Khlopets pid areshtom.” September 3, 2015. https://kp.20minut.ua/Podii/sche-odnogo-kamyanchanina-sergiya-kraynyaka-pidozryuyutv-organizatsiy-10459963.html. (Accessed February 9, 2018.)

24 kanal. 2014. “Uriad tekhnokrativ, — meta partii, “-Samopomich.” October 29, 2014. http://24tv.ua/uryad_tehnokrativ_ meta_partiyi_samopomich_n503152. (Accessed February 13, 2018.)

112. ua. 2015. "'Pravyy sektor': Vykhid Yarosha dozvolyt rukhovi peretvorytysia na 'poslidovnu revoliutsiinu sylu'." February 28, 2015. https://web.archive.org/web/20160131070210; http://ua.112.ua/suspilstvo/pravyi-sektor-vykhid-yarosha-dozvolytrukhovi-peretvorytysia-v-poslidovnu-revoliutsiinu-sylu-281922.html. (Accessed May 12, 2021.)

112. ua. 2016a. "Lyashko v Rade oblila sokom rossiyanka - eks-boyets batal'ona 'Aydar.” December 8, 2016. https://web. archive.org/web/20161211140701; http://112.ua/politika/lyashko-v-rade-oblila-sokom-rossiyanka-boec-batalona-aydar357995.html. (Accessed May 12, 2021.)

112. ua. 2016b. "Poroshenko pro batalion 'Kulchyts'koho': My shanuiemo kozhnoho z zhyvykh heroiv i pamiataiemo tykh, khto ne povernuvsia." March 16, 2016. https://web.archive.org/web/20180123035100; http://ua.112.ua/suspilstvo/por oshenko-pro-batalion-kulchytskoho-my-shanuiemo-kozhnoho-z-zhyvykh-heroiv-i-pamiataiemo-tykh-khto-ne-povernuv sia-298497.html. (Accessed May 12, 2021.)

Acosta, Benjamin. 2014. "Bombs to Ballots: When Militant Organizations Transition to Political Parties." The Journal of Politics 76 (3): 666-683.

Ahram, Ariel. 2011. Proxy Warriors: The Rise and Fall of State-Sponsored Militias. Stanford, CA: Stanford University Press.

Aliyev, Huseyn. 2018. "Bewaffnete Freiwilligenbataillone: Informelle Machthaber in der Ukraine.” Ukraine-Analysen (205): $2-5$.

Antykor. 2015. "Mykhailo Havryliuk: Odnym slovom, v Verkhovnii Radi - bardak; Liudy pryishly ne na robotu, a butsimto v rozvazhalnyy tsentr.” March 31, 2015. http://antikor.com.ua/articles/34664-mihajlo_gavriljuk_odnim_slovom_v_verhov nij_radi_-_bardak._ljudi_prijshli_ne_na_robotu_a_butsimto_v_r. (Accessed February 13, 2018.)

Atanasov, Vitalii. 2016. "Kryvyy Rih Needs an Alternative." Open Democracy, February 23, 2016. http://www.opendemocracy. net/od-russia/vitalii-atanasov/kryvyi-rih-needs-alternative. (Accessed July 13, 2018.)

Azov.Press. 2015. "Pro 'Azov.” Azov.Press, December 8, 2015. http://azov.press/ukr/pro-azov. (Accessed February 9, 2018.) BBC Ukraina. 2014. "U Rosii Savchenko zaareshtuvaly do kintsya lita.” July 9, 2014. http://www.bbc.co.uk/ukrainian/politics/ 2014/07/140709_savchenko_update_arrest_dt.shtml. (Accessed February 13, 2018.)

BBC Ukraina. 2015a. "Melnychuk z 'Aidaru': U mene ye ambitsii hetmana Ukrainy.” February 7, 2015. http://www.bbc.com/ ukrainian/politics/2015/02/150205_melnychuk_ie_sx. (Accessed February 13, 2018.) 
BBC Ukraina. 2015b. “'Pravyy sektor' ne pide na mistsevi vybory.” July 21, 2015. http://www.bbc.com/ukrainian/politics/2015/ 07/150721_right_sector_elections_hk. (Accessed February 8, 2018.)

BBC Ukraina. 2016. “Komendant Rady: Khto takyy Andriy Parubii?” April 14, 2016. https://www.bbc.com/ukrainian/politics/ 2016/04/160414_parubiy_profile_upd_ms_sx. (Accessed August 29, 2018.)

Berdyns'kykh, Kristina. 2020. “Bunt u Sluzi narodu: Interviu z nardepom Chernevym, spivavtorom zvernennia do Zelens'koho stosovno perehovoriv Yermaka z RF.” NV, March 20. https://nv.ua/ukr/ukraine/politics/nardep-zi-slugi-narodu-yegorchernyev-pro-zustrich-z-yermakom-i-peregovori-z-rf-novini-ukrajini-50076838.html. (Accessed July 5, 2020.)

Bukovskiy, Dmitriy. 2015. “Pochemu Kolomoisk‘yy zakryl 'Pravyy sektor.” Delovaya stolitsa, November 11, 2015. http:// www.dsnews.ua/politics/pochemu-kolomoyskiy-zakryl-pravyy-sektor-11112015170000. (Accessed February 10, 2018.)

Buniak, Yuliia. 2014. “Komandyry batalionu 'Shakhtars'k': 95\% militsiy potribno zvilnyty. Tse vorohy." Obozrevatel, July 18, 2014. https://www.obozrevatel.com/interview/85209-komandiryi-batalona-shahtersk-95-militsii-nuzhno-uvolit-etovragi.htm. (Accessed February 13, 2018.)

Burdyha, Ihor. 2018. "Nevydymyy lehion: Ukrains'ki dobrovoltsi, yaki ne khochut lehalizuvatysia.” Deutsche Welle Ukraine, October 30, 2018. https://p.dw.com/p/37Jvn. (Accessed May 12, 2021.)

Butkevych, Bohdan. 2016. “Chomu 'Samopomich' vtrachae pozytsiyi.” Tyzhden, June 30, 2016. http://tyzhden.ua/Politics/ 168506. (Accessed February 13, 2018.)

Chernyshev, Roman. 2014a. "Lyudi i vily: Analiz predvybornogo spiska partii Olega Lyashko.” Liga.Novosti, September 26, 2014. http://news.liga.net/articles/politics/3416556-lyudi_i_vily_analiz_predvybornogo_spiska_partii_olega_lyashko. htm. (Accessed February 13, 2018.)

Chernyshev, Roman. 2014b. "Pod prikrytiyem kombatov: Narodnyy front opredelilsya so spiskom.” Liga.Novosti, September 14, 2014. http://news.liga.net/politics/articles/pod_prikrytiem_kombatov_narodnyy_front_opredelilsya_so_spiskom. (Accessed February 13, 2018.)

Chernyshev, Roman. 2014c. "Pozdniy start: Analiz predvybornogo spiska 'Narodnogo fronta." Liga.Novosty, September 29, 2014. http://news.liga.net/articles/politics/3429844-kokteyl_sezona_analiz_predvybornogo_spiska_narodnogo_fronta. htm. (Accessed February 13, 2018.)

Chesno. 2020. "Bohdanets Andriy Volodymyrovych.” https://www.chesno.org/politician/157521/. (Accessed July 6, 2020.)

Comments.ua. 2017. "V chom osnova partii Taruty." Comments.ua, October 24, 2017. https://comments.ua/politics/599224-vosnova-partii-taruti.html. (Accessed February 9, 2018.)

Coynash, Halya. 2017. "Russian Who Defended Ukraine in Donbas Driven Out to Face Imprisonment in Russia." Human Rights in Ukraine, December 5, 2017. http://khpg.org/en/index.php?id=1512422913. (Accessed February 13, 2018.)

Dashchuk, Sasha. 2014. "Hrytsenko: Rse niyaka ne ATO - tse derzhavna zrada!” Presa Ukrainy, April 29, 2014. http:// uapress.info/uk/news/show/23146. (Accessed February 10, 2018.)

Davidzon, Vladislav. 2018. "Right-Wing Ukrainian Leader Is (Surprise) Jewish, and (Real Surprise) Proud of It.” Tabletmag. com, December 1, 2018. https://www.tabletmag.com/jewish-news-and-politics/187217/borislav-bereza. (Accessed November 15, 2019.)

Demokratychni initsiatyvy. 2014. “Vid Maidanu-taboru do Maidanu-sichi: Shcho zminylosia?” Demokratychni initsiatyvy, February 6, 2014. http://dif.org.ua/article/vid-maydanu-taboru-do-maydanu-sichi-shcho-zminilosya. (Accessed February 8, 2018.)

Demokratychni initsiatyvy. 2017. “Hromads'ka dumka, hruden-2017: Vyborchi reitynhy i reitynhy doviry." Demokratychni initsiatyvy, December 2017. http://dif.org.ua/uploads/doc/11718337605a665adc7b97d3.95892743.doc. (Accessed February 13, 2018.)

Depo.ua. 2017. “Avakov prezentuvav knyhu ta rozpoviv, yak z Parubiem i Turchynovym orhanizovuvaly dobrobaty.” Depo.ua, January 27, 2017. https://dn.depo.ua/ukr/dn/2016/04/avakov-prezentuvav-knigu-ta-rozpoviv-yak-z-parubiyem-i-turchino vim-organizovuvali-dobrobati-20170127508785. (Accessed August 29, 2018.)

Dorosh, Svitlana. 2015. "Shcho khovaetsia za 'UKROP'om.”BBC Ukrayina, June 24, 2015. http://www.bbc.com/ukrainian/ politics/2015/06/150624_ukrop_new_party_sd. (Accessed February 10, 2018.)

Dzerkalo tyzhnia. 2015. “Biitsi 'Sichi' vykorystovuiut tabelnu zbroiu batalonu 'Dnipro-1' - Denysenko.” Dzerkalo tyzhnia, March 23, 2015. http://dt.ua/UKRAINE/biyci-sichi-vikoristovuyut-tabelnu-zbroyu-batalonu-dnipro-1-denisenko-167672_ .html. (Accessed February 13, 2018.)

Espreso.tv. 2016. “Sestra Savchenko kazhe, shcho Nadiia vyishla z 'Bat'kivshchyny' shche v zhovtni.” Espreso.tv, December 13, 2016. http://espreso.tv/news/2016/12/13/sestra_savchenko_kazhe_scho_nadiya_vyyshla_z_quotbatkivschynyquot_ sche_v_zhovtni. (Accessed February 13, 2018.)

Expres. 2014. “Poroshenko pryishov u VR pid okhoronoiu batalionu 'Donbas.”' July 4, 2014. https://web.archive.org/web/ 20140821005828/http://expres.ua/digest/2014/07/04/108900-poroshenko-pryyshov-vr-pid-ohoronoyu-batalyonu-donbas. (Accessed May 12, 2021.)

Facenews. 2015. “Skoropads'kyy Artem.” February 8, 2015. https://www.facenews.ua/file/2015/296174/. (Accessed November 25, 2015.)

Fedorenko, Kostyantyn, Olena Rybiy, and Andreas Umland. 2016. “The Ukrainian Party System before and after the 2013-2014 Euromaidan." Europe-Asia Studies 68 (4): 609-630. 
Francis, Diane M. 2015. “Ukraine's Volunteers Saving the Day.” The Huffington Post, July 23, 2015. http://www.huffingtonpost. com/diane-m-francis/ukraines-volunteers-savin_b_7832224.html. (Accessed February 8, 2018.)

Hahn, Gordon M. 2015. “Weimar Maidan Ukraine.” Russian \& Eurasian Politics, January 20, 2015. http://gordonhahn.com/ 2015/01/20/weimar-maidan-ukraine/. (Accessed November 18, 2019.)

Halas. 2015. “'Bat'kivshchyna’ vede u mis'kradu kombata batalionu 'Ternopil.” Halas, October 1, 2015. http://galas.te.ua/2015/ 10/батьківщина-веде-у-міськраду-комб/. (Accessed February 13, 2018.)

Hladka, Kateryna, Dmytro Khromakov, Veronika Myronova, Ol'ha Pluzhnyk, Oleh Pokal'chuk, Ihor Rudych, Vasylisa Trofymovych, and Artem Shevchenko. 2016. Dobrobaty: Istoriia bataloniv, shcho vriatuvaly krainu. Kharkiv: Folio.

Gonta, Borys. 2015. "Zhyznennyi put' Igoria Krivoruchko: Cherez ternii k Liashko.” Bukvy, October 1, 2015. https://bykvu.com/ mysli/9746-zhiznennyj-put-igorya-krivoruchko-cherez-ternii-k-lyashko. (Accessed February 13, 2018.)

Hromadians'ka pozytsiia - L'vivs'ka oblast'. 2015. "Viys'kovi podyakuvaly l'vivs'kym aktyvistam 'Hromadyans'koyi pozytsii' za dopomohu.” Facebook, July 14, 2015. https://www.facebook.com/GP.Lviv.Obl/posts/1498523790439635. (Accessed February 10, 2018.)

Hromadske.ua. 2014. "Spysok Tiahnyboka." Twitter, September 14, 2014. https:/twitter.com/HromadskeUA/status/ 511149712939155457. (Accessed February 8, 2018.)

Hrytsenko, Anatolii. 2014. "Viis'kovym peredano novi topohrafichni karty vid 'Hromadians'koi pozytsii." Grytsenko.com.ua, August 21, 2014. https://web.archive.org/web/20140831015335/http://grytsenko.com.ua/news/view-viys-kovym-peredanonovi-topohrafichni-karty-vid-hromadjans-koji-pozytsiji.html. (Accessed May 12, 2021.)

Informator. 2016. "Dobrovol'chyy rukh Poroshenko abo dyskredytue, abo znyshchyt', - Parasiuk." July 7, 2016. https:// informator.news/arhiv2016/?p=227959. (Accessed February 13, 2018.)

Kachura, Dmytryy. 2016. “Chomu Filatov oholosyv viinu Kolomois'komu.” Depo.ua, October 20, 2016. https://www.depo.ua/ ukr/politics/chomu-filatov-ogolosiv-viynu-kolomoyskomu-20102016190000. (Accessed February 10, 2018.)

Kaliakyna, Alena. 2015. "Myr mozhlyvyy lyshe pislia peremohy nad rosiis'kym ahresorom - Tiahnybok." 032.ua, August 25, 2015. https://www.032.ua/article/936505. (Accessed February 8, 2018.)

Karpiak, Oleh. 2014. "Chy stanut dobrovolchi bataliony yadrom novoi armii." BBC Ukraina, August 6, 2014. https://www. bbc.com/ukrainian/politics/2014/08/140805_volunteer_batallions_ko. (Accessed August 29, 2018.)

Kharkiv Human Rights Protection Group. 2014. “Try roky tomu na skhodi Ukrainy pochalasia ATO.” Kharkiv Human Rights Protection Group, April 14, 2014. http://khpg.org/index.php?id=1492173145. (Accessed November 18, 2020.)

Khomenko, Sviatoslav. 2016. "Richnytsia vybukhiv 31 serpnia: Shcho my znaemo?” BBC Ukraina, August 31, 2016. http:// www.bbc.com/ukrainian/politics/2016/08/160831_31aug_anniversary_sx. (Accessed February 9, 2018.)

KMIS. 2017. "Reitynh pidtrymky partii i politychnykh lideriv: Hruden 2017 roku." Kyivs'kyy mizhnarodnyy instytut sotsiolohii (KMIS), February 13, 2017. http://www.kiis.com.ua/?lang=ukr\&cat=reports\&id=730\&page=1. (Accessed December 19, 2017.)

Kondratenko, Andrii. 2014. “Komandyr polku 'Azov’ Andriy Bilets'kyy: Ti, khto prolyvae krov za Ukrainu, povynni maty svii holos u vladi.” UNIAN, October 11, 2014. https://www.unian.ua/politics/994779-komandir-polku-azov-andriy-biletskiy-tihto-prolivae-krov-za-ukrajinu-povinni-mati-sviy-golos-u-vladi.html. (Accessed February 9, 2018.)

Korrespondent. 2015. “Miniust zareyestruvav partiiu Kolomois'koho.” June 18, 2015. https://ua.korrespondent.net/ukraine/ 3529272-minuist-zareiestruvav-partiui-kolomoiskoho. (Accessed February 10, 2018.)

Korrespondent. 2016a. "Poroshenko otvetil na aktsii 'Azova.” May 20, 2016. http://korrespondent.net/ukraine/3685533poroshenko-otvetyl-na-aktsyy-azova. (Accessed February 13, 2018.)

Korrespondent. 2016b. “Sprava 'Tornado': Shcho slid znaty pro novyy skandal.” August 3, 2016. http://ua.korrespondent.net/ ukraine/3726408-sprava-tornado-scho-slid-znaty-pro-novyi-skandal. (Accessed February 13, 2018.)

Kryvko, Anton. 2020. "Kozhna druha partiia zminiue nazvu - osoblyvosti partbudivnytstva v Ukraini." Chesno, June 11, 2020. https://www.chesno.org/post/4053/. (Accessed July 5, 2020.)

Kuzmenko, Evhenyi. 2016a. "Ruslan Koshulyns'kyy: 'Rosiis'koiu movoiu vidrizaiut vukha, nosy, henitalii, katuiut tvoikh druziv. Khocha b zarady tsoho: vidiidy vid nei!” Tsenzor.NET, December 19, 2016. https://ua.censor.net.ua/resonance/ 419675/ruslan_koshulynskyyi_rosiyiskoyu_movoyu_vidrizayut_vuha_nosy_genitaliyi_katuyut_tvoyih_druziv_hocha.

(Accessed February 8, 2018.)

Kuzmenko, Evhenyi. 2016b. "Spiker 'Pravoho sektora' Artem Skoropads'kyy: '... A za kilka rokiv u nas Khreshchatykom khodytymut holi muzhyky. Nam tse potribno chy ni? Nam tse ne potribno.” Tsenzor.NET, June 9, 2016. https://ua.censor. net.ua/resonance/392561/spiker_pravogo_sektora_artem_skoropadskyyi_a_za_kilka_rokiv_u_nas_hreschatykom_hodyty mut_goli_mujyky. (Accessed February 8, 2018.)

Lapin, Ihor. 2018b. “Aidar.” Igorlapin.com.ua, August 29, 2018. https://web.archive.org/web/20191228193039/http:// igorlapin.com.ua/aidar.php. (Accessed May 12, 2021.)

Lashchenko, Oleksandr. 2015. "Yakshcho na nas tysnutymut, liudy zakhystiat 'Pravyy sektor' - Artem Skoropads'kyy." Radio Svoboda, July 22, 2015. https://www.radiosvoboda.org/a/27147383.html. (Accessed July 5, 2020.)

LB.ua. 2014. "V zonu ATO z Kyeva vyrushae batalion 'Sich.”' LB.ua, August 26, 2014. http://ukr.lb.ua/news/2014/08/26/ 277259_zonu_ato_kieva_otpravlyaetsya.html. (Accessed February 8, 2018.)

Lehion Svobody. n.d. “Lehion Svobody.” Facebook. https://www.facebook.com/legion.svobody/. (Accessed February 14, 2018.) 
Lelych, Mylan. 2016. "Yesli by kto-to nazval menya Belym vozhdom, byl by on bit, — Andrey Biletskiy." Fokus, October 4, 2016. https://focus.ua/country/358170/. (Accessed February 9, 2018.)

Liga.Novosty. 2014. "Partiya Sadovogo utverdila spisok kandidatov na vybory v Radu.” Liga.Novosty, September 12, 2014. http://news.liga.net/news/politics/3267517-partiya_sadovogo_utverdila_spisok_kandidatov_na_vybory_v_radu.htm. (Accessed February 13, 2018.)

Likhachev, Viacheslav. 2013. "Social-Nationalists in the Ukrainian Parliament: How They Got There and What We Can Expect of Them." Russian Politics and Law 51 (5): 75-85.

Likhachov, Viacheslav. 2018. "Chomu perebilshennia roli ultrapravykh v ukrains'kii revoliutsii ne mensh nebezpechne, nizh prymenshennia.” Zaborona, May 3, 2018. https://zaborona.com/likhachov-column/. (Accessed July 8, 2018.)

Likhachov, Viacheslav. 2020. Vid Maidanu pravoruch: Revoliutsiia, viina i ultrapravi partii v Ukraini (2013-2016 rr.). Kyyiv: Krytyka.

Lutsenko, Ihor. 2014. "Pidstvolnyky dlia 'Azova.” Ukrains'ka pravda, August 18, 2014. http://blogs.pravda.com.ua/authors/ lutsenko/53f11d4d496c3/. (Accessed February 13, 2018.)

Lytvynova, Natalia. 2015. “Deputat-kombat Yuriy Bereza: Na mistsi Heleteia ya b zastrelyvsia pislia Ilovais'ka.” Glavkom, April 24, 2015. http://glavcom.ua/interviews/129391-deputat-kombat-jurij-bereza-na-mistsi-geleteja-ja-b-zastrelivsja-pisljailovajska.html. (Accessed February 10, 2018.)

Mamon, Marcin. 2015. “The Cross and the Sword: The Making of a Christian Taliban in Ukraine." The Intercept, March 18, 2015. https://theintercept.com/2015/03/18/ukraine-part-3/. (Accessed February 13, 2018.)

Naiem, Mustafa. 2014. “Za lashtunkamy 'Pravoho sektoru.”' Ukrains'ka pravda, April 1, 2014. http://www.pravda.com.ua/ articles/2014/04/1/7020952/. (Accessed February 8, 2018.)

Nadvirnians’ka Svoboda. 2015. “Svobodivtsi na viyni: Eks-vitse-spiker, deputaty ta Tiahnybok.” Holos Svobody, June 26, 2015. svoboda-nad.org.ua/news/206-svobodivtsi-na-viini-eks-vitse-spiker-deputaty-ta-tiahnybok. (Accessed May 12, 2021.)

Narodnyy front. 2018. "Mikhail Bondar." https://nfront.org.ua/team/member-details/mykhailo-bondar. (Accessed February 13, 2018.)

Obozrevatel. 2014. “Eksperty prizvali Yatsenyuka ne vydvigat' kombata ‘Azova' kandidatom v nardepy.” September 15, 2014. https://www.obozrevatel.com/politics/01652-ekspertyi-prizyivayut-yatsenyuka-ne-vyidvigat-kombata-azova-kandidatomv-nardepyi.htm. (Accessed February 10, 2018.)

Obozrevatel. 2016. “Zhivi, boris' i lyubi: Korban i Filatov trogatel'no pozdravili Yarosha s dnom rozhdeniya." September 30, 2016. https://www.obozrevatel.com/society/92534-zhivi-boris-i-lyubi-korban-i-filatov-trogatelno-pozdravili-yaroshas-dnem-rozhdeniya.htm. (Accessed February 10, 2018.)

Odintsova, Anastasiia. 2019. “Dose na deputativ novoi Rady : Yana Zinkevych.” NV, July 30, 2019. https://nv.ua/ukr/ukraine/ vru-deputaty/yana-zinkevich-medik-volonter-i-deputat-biografiya-foto-50034736.html. (Accessed July 5, 2020.)

Pidvezianyi, Mykola, and Kateryna Peshko. 2016. "Vpershe vyznaiu - pered vyboramy my domovylys z Lovochkinym: Inshoho vykhodu prosto ne bulo - Oleh Liashko.” Glavkom, September 9, 2016. http://glavcom.ua/interviews/oleg-lyashko-vpersheviznayu-pered-viborami-mi-domovilis-z-lovochkinim-inshogo-vihodu-prosto-ne-bulo-371621.html. (Accessed February 13, 2018.)

Pravyy sektor. 2017a. “Druh 'Sirko’ pro realii rosiis'ko-ukrains'koi viiny.” January 18, 2017. https://pravyysektor.info/borotba/ drug-sirko-pro-realiyi-rosiysko-ukrayinskoyi-viyny. (Accessed February 8, 2018.)

Pravyy sektor. 2017b. “Na fronti.” July 25, 2017. https://web.archive.org/web/20170725213112/http://pravyysektor.info/sec tion/na-fronti. (Accessed February 8, 2018.)

Pravyy sektor. 2017c. “Ostriv Krym.” May 27. https://pravyysektor.info/poglyad/ostriv-krym. (Accessed February 8, 2018.)

Press Post. 2014. “Batal'on 'Donbass' vydvinul ul'timatum Poroshenko.” November 3, 2014. https://web.archive.org/web/ 20150725124223/http://press-post.net/batalon-donbass-vydvinul-ultimatum-poroshenko. (Accessed May 12, 2021.)

Radio Svoboda. 2016. "Deputat Rady Mosiichuk hotovyy do povtornoi protsedury zniattia nedotorkannosti." June 9, 2016. http://www.radiosvoboda.org/a/news/27788708.html. (Accessed February 13, 2018.)

Rinhis, Anastasiya. 2016. “Hats'ko ta yoho komanda: 'DemAlians' 2.0.” Ukrains'ka pravda, July 26, 2016. http://www.pravda. com.ua/articles/2016/07/26/7115976/. (Accessed February 10, 2018.)

Rivnens'ki novyny. 2014. "Kolomois'kyy cherez Liashka prypynyv finansuvannia batalioniv 'Shakhtars'k' ta 'Azov.” August 2, 2014. https://web.archive.org/web/20181022234924/http://rivnenews.com.ua/index.php/2011-10-13-10-01-08/4579kolomoiskyi-cherez-liashka-prypynyv-finansuvannia-batalioniv-shakhtarsk-ta-azov. (Accessed May 12, 2021.)

Ruzhyns'kyy, Serhii. 2014. "Navishcho Petro Poroshenko znyshchuie dobrovolchi bataliony?” iPress.ua, August $21,2014$. http://ipress.ua/articles/navishcho_petro_poroshenko_znyshchuie_dobrovolchi_batalyony_81076.html. (Accessed February 13, 2018.)

Samopomich Kharkiv. 2014. “Batalionu 'Kharkiv-1' vid 'Samopomochi.”' Samopomich Kharkiv, December 19, 2014. http:// kharkiv.samopomich.ua/news/bataljonu-harkiv-1-vid-samopomochi/. (Accessed February 13, 2018.)

Sazonov, Kyrylo. 2015. “Komandyr batalionu 'Sich' Oleksandr Pysarenko: 'My zaraz budemo maty kolosalnu problemu z biitsiamy, yaki povertaiutsia $\mathrm{z}$ frontu.” Tsenzor.NET, September 25, 2015. https://censor.net.ua/resonance/353520/koman dir_batalyionu_sch_oleksandr_pisarenko_mi_zaraz_budemo_mati_kolosalnu_problemu_z_byitsyami_yak. (Accessed February 8, 2018.) 
Shekhovtsov, Anton. 2014. "From Electoral Success to Revolutionary Failure: The Ukrainian Svoboda Party." Eurozine, March 5, 2014. https://www.eurozine.com/from-electoral-success-to-revolutionary-failure/. (Accessed July 15, 2016.)

Shestopal, Nataliia, and Romaniia Horbach. 2014. "Pry Yushchenkovi buv bezlad, za Yanukovycha - svavillia: S’ohodni treba rozbudovuvaty krainu, pryvodyty ii v poriadok - Oleksandr Tretiakov.” Gazeta.ua, November 26, 2014. http://gazeta.ua/ articles/opinions-journal/_pri-uschenkovi-buv-bezlad-za-anukovicha-svavillya-sogodni-treba-rozbudovuvati-krayinu-pri voditi-yiyi-v-poryadok/585362. (Accessed February 13, 2018.)

Shuklinov, Potr. 2014. “Assorti ot Poroshenko: Kto yest’ kto v spiske prezidentskogo bloka.” Liga.Novosti, October $23,2014$. http://news.liga.net/articles/politics/3740506-komanda_poroshenko_kto_est_kto_v_spiske_prezidentskogo_bloka.htm.

(Accessed February 13, 2018.)

Skorokhod, Olha. 2017. '“Lakshcho khtos dumae, shcho tsia viina za Donbas i Krym, to tse ne tak,' - eks-hlava Sums'koi oblrady, yakyy pishov dobrovoltsem v ATO, Semen Salatenko.” Tsenzor.NET, March 18, 2017. https://censor.net.ua/ resonance/431956/esli_ktoto_dumaet_chto_eta_voyina_za_donbass_i_za_krym_to_eto_ne_tak_eksglava_sumskogo_ oblsoveta_ushedshiyi. (Accessed February 13, 2018.)

Slovo i Dilo. 2014. “'Hromadians'ka pozytsiia' Hrytsenka: Persha 20-ka spysku.” October 7, 2014. https://www.slovoidilo.ua/ articles/5137/2014-10-07/grazhdanskaya-poziciya-gricenko-pervaya-20-ka-spiska.html. (Accessed February 10, 2018.)

Slovo i Dilo. 2020. "Bondar Mykhailo Leontiiovych." https://www.slovoidilo.ua/persony/bondar-mykhailo-leontiiovych. (Accessed July 6, 2020.)

S’ohodni. 2014a. “Batalion 'Aidar' isnuvatyme i prodovzhyt vykonannia svoikh zavdan.” June 24, 2014. http://ukr.segodnya.ua/ regions/donetsk/batalon-aydar-budet-sushchestvovat-i-prodolzhit-vypolnenie-svoih-zadach-531197.html. (Accessed February 13, 2018.)

S’hodni. 2014b. "Syn Poroshenko rasskazal, kak voeval na Donbasse pod chuzhoi familiei." November 29, 2014. http:// www.segodnya.ua/politics/society/syn-poroshenko-rasskazal-kak-voeval-na-donbasse-pod-chuzhoy-familiey-573186. html. (Accessed February13, 2018.)

Sokyrchuk, Nataliia. 2017. "Molodi ta zukhvali. Parasiuk ta yoho pryntsypy." Glavcom, April 8. http://glavcom.ua/interviews/ molodi-ta-zuhvali-parasyuk-ta-yogo-principi-407859.html. (Accessed February 10, 2018.)

Stek, Levko. 2016. “Stvoriuetsia naimana armiia, yaka ne zdatna peremahaty - komandyr 'Karpats'koi Sichi." Radio Svoboda, April 13, 2016. http://www.radiosvoboda.org/a/27673230.html. (Accessed February 8, 2018.)

Stempits'kyy, Andrii. 2017. “'DUK PS' i monopoliia derzhavy na sylu.” Pravyy Sektor, May 29, 2017. https://pravyysektor.info/ poglyad/andriy-stempickyy-duk-ps-i-monopoliya-derzhavy-na-sylu. (Accessed February 8, 2018.)

Svoboda. 2015a. "Do richnytsi stvorennia 'Karpats'koi Sichi': Shliakh vid volonterstva do shturmovoi roty.” February 8, 2015. http://svoboda.org.ua/news/events/00014998/. (Accessed August 26, 2015.)

Svoboda. 2015b. "Narodnyy deputat Oleksandr Marchenko buduye oboronni sporudy na peredoviy." June 5, 2015. http:// svoboda.org.ua/news/events/00014013/. (Accessed February 8, 2018.)

Svoboda. 2015c. "XXX z"yizd VO 'Svoboda." February 9, 2015. http://svoboda.org.ua/media/videos/00012753/. (Accessed February 8, 2018.)

Tiahnybok, Oleh. 2015. “Svoboda i Chest! 'Sich' - rik u viini za Ukrainu.” Svoboda, June 12, 2015. http://svoboda.org.ua/news/ articles/00014078/. (Accessed February 8, 2018.)

Tsentralna vyborcha komisiia. 2014a. "Pozacherhovi vybory narodnykh deputativ Ukrainy 26 zhovtnia 2014 roku: Prohrama politychnoi partii 'Pravyy sektor.” https://www.cvk.gov.ua/pls/vnd2014/showdoc2pf7171=158pid409=27.doc. (Accessed February 8, 2018.)

Tsentralna vyborcha komisiia. 2014b. "Vidomosti pro kandydata v narodni deputaty Ukrayiny: Holovko Stepan Serhiyovych." http://www.cvk.gov.ua/pls/vnd2014/WP407?PT001F01=910\&pf7201=9093. (Accessed February 10, 2018.)

Tsentralna vyborcha komisiia. 2014c. "Vidomosti pro pidrakhunook holosiv v odnomandatnomu vyborchomu okruzi: Odnomandatnyy vyborchyy okruh №39 (Dnipropetrovs’ka oblast').” https://www.cvk.gov.ua/pls/vnd2014/wp040pt001f01= 910pf7331=39.html. (Accessed February 8, 2018.)

Tsentralna vyborcha komisiia. 2019a. "Vyborchyy spysok: Politychna partiia Vseukrains'ke ob'ednannia 'Svoboda." https:// www.cvk.gov.ua/pls/vnd2019/wp406pt001f01=919pf7171=355pf72035=0. (Accessed August 6, 2020.)

Tsentralna vyborcha komisiia. 2019b. "Vybory narodnykh deputativ Ukrayiny. Pozacherhovi 21.07.2019: Pidsumky holosuvannya po okruhakh.” https://www.cvk.gov.ua/pls/vnd2019/wp306_npt001f01=919.html. (Accessed August 6, 2020.)

Tsentralna vyborcha komisiia. 2019c. "Vybory narodnykh deputativ Ukrayiny. Pozacherhovi 21.07.2019: Rezul'taty po bahatomandatnomu vyborchomu okruhu." https://www.cvk.gov.ua/pls/vnd2019/wp300pt001f01=919.html. (Accessed August 6, 2020.)

Tsenzor.NET. 2017. “'Dobrovolchi bataliony zaklaly ideolohiiu rozvytku sylnoi patriotychnoi nezalezhnoi krainy,' - Turchynov na prezentatsii knyhy 'Dobrobaty’: FOTOreportazh.” January 28, 2017. http://ua.censor.net.ua/photo_news/425325/dobro volchi_batalyiony_zaklaly_ideologiyu_rozvytku_sylnoyi_patriotychnoyi_nezalejnoyi_krayiny_turchynov. (Accessed February 13, 2018.)

TSN. 2014. "Podvyhy Lyashka v zoni ATO vyiavliaetsia dobre zezhesovanoiu videopostanovkoiu." October 24, 2014. https:// tsn.ua/vybory-v-rady2014/podvigi-lyashka-v-zoni-ato-viyavilisya-dobre-zrezhisovanoyu-videopostanovkoyu-384754.

html. (Accessed February 13, 2018.) 
TSN. 2015. "Natsionalistiv yaki voiuiut na Donbasi ob'ednaly v 'Lehion Svobody.” April 25, 2015. https://tsn.ua/politika/ nacionalistiv-yaki-voyuyut-na-donbasi-ob-yednali-v-legion-svobodi-423603.html. (Accessed February 8, 2018.)

Ukrains'ka pravda. 2014. “Avakov: Poroshenko ne rozpuskav bataliony.”Ukrains'ka pravda November 11, 2014. http://www. pravda.com.ua/news/2014/11/11/7043879/. (Accessed February 9, 2018.)

Ukrains'ka pravda. 2015a. "Hranatu kynuv svobodivets iz batal'yonu 'Sich' - Avakov.” August 31, 2015. http://www.pravda. com.ua/news/2015/08/31/7079662/. (Accessed February 9, 2018.)

Ukrains'ka pravda. 2015b. “Kandidat v meri Pavlograda ot 'Ukropa' popal v DTP.” November 8, 2015. http://www.pravda. com.ua/rus/news/2015/11/8/7087937/. (Accessed February 10, 2018.)

Ukrains'ka pravda. 2015c. "Na mistsevykh vyborakh pokrashchyly rezultaty tilky krytyky vlady." November 9, 2015. http:// www.pravda.com.ua/news/2015/11/9/7088039/. (Accessed February 9, 2018.)

Ukrains'ka pravda. 2015d. “Sud zaareshtuvav svobodivtsya Syrotiuka.” September 11, 2015. http://www.pravda.com.ua/news/ 2015/09/11/7081012/. (Accessed February 9, 2018.)

Ukrains'ka pravda. 2016a. “Azov' stvoryv partiiu: Khoche vidnovlennya yadernoho potentsialu ta lehalizatsii vohnepal'noi zbroi.” October 14, 2016. http://www.pravda.com.ua/news/2016/10/14/7123637/. (Accessed February 9, 2018.)

Ukrains'ka pravda. 2016b. "Denysenko zayavyv, shcho yde z 'Ukropu' cherez pozytsiyu shchodo Novyns'koho.” December 8, 2016. http://www.pravda.com.ua/news/2016/12/8/7129246/. (Accessed February 13, 2018.)

Ukrains'ka pravda. 2016c. “Orhanizovani Partiini Hrupy-2: Piat stovpiv 'Narodnoho frontu.” November 1, 2016. http:// www.pravda.com.ua/articles/2016/11/1/7125375/. (Accessed February 13, 2018.)

Ukrains'ka pravda. 2016d. “'UKROP’ vysuvae v mery Kryvoho Rohu kuratora batal'yonu 'Kryvbas.”' February 26, 2016. http:// www.pravda.com.ua/news/2016/02/26/7100411/. (Accessed February 10, 2018.)

Ukrains'ka pravda. 2017a. “Miniust zareestruvav partiiu Savchenko.” July 19, 2017. https://www.pravda.com.ua/news/2017/07/ 19/7150044/. (Accessed February 13, 2018.)

Ukrains'ka pravda. 2017b. "Saakashvili i Semenchenko ne zbyraiutsia prypyniaty aktsiiu protestu." October 19, 2017. http:// www.pravda.com.ua/news/2017/10/19/7159017/. (Accessed February 13, 2018.)

Ukrains'ka pravda. 2018. “Pid Radoiu pomianuly zahyblykh vid boiovoi hranaty rik tomu hvardiitsiv.” August 31, 2018. http:// www.pravda.com.ua/news/2016/08/31/7119174/. (Accessed February 9, 2018.)

Ukrains'ka pravda. 2019. “Spysok partii 'Holos': Liudy Vakarchuka i Fialy ta aktyvisty iz zakhidnoiu osvitoiu.” June 25, 2019. https://www.pravda.com.ua/articles/2019/06/25/7219080/. (Accessed July 5, 2020.)

Ukrinform. 2014. "'Right Sector' Ready to Send 5,000 People to the East." July 19, 2014. https://web.archive.org/web/ 20140719005625/https://www.ukrinform.ua/eng/news/right_sector_ready_to_send_5000_people_to_east_323991. (Accessed December 12, 2020.)

UKROP. 2018. “'UKROP' i 'Pravyy sektor' poydut na mestnyye vybory otdel'no - Filatov.” UKROP, February 8, 2018. http:// www.ukrop.com.ua/uk/news/text/17-1031408458. (Accessed Novenber 12, 2018.)

Umland, Andreas. 2016. “Dobrovol'cheskie vooruzhennye formirovaniia v postmaidannoi Ukraine." Politychna Krytyka, March 15, 2016. http://ukraine.politicalcritique.org/2016/03/dobrovolcheskie-vooruzhyonnye-formirovaniya-i-radikalnyjnatsionalizm-v-poslemajdannoj-ukraine/. (Accessed 9 February, 2018.)

UNIAN. 2017. “Turchynov zghadav, yak u 2014 rotsi dobrovoltsi zupynyly sproby armii Putina pryvesty 'lehitymnoho.” UNIAN, January 27, 2017. https://www.unian.ua/politics/1746931-turchinov-zgadav-yak-u-2014-rotsi-dobrovoltsi-zupi nili-sprobi-armiji-putina-privesti-legitimnogo.html. (Accessed February 8, 2018.)

Vasylchenko, Yurii. 2014. “Liashko zalyshyvsia bez batalioniv.” Delovaya stolitsa, September 12, 2014. http://www.dsnews.ua/ politics/lyashko-zalishivsya-bez-batalyoniv-12092014143500. (Accessed February 13, 2018.)

Verkhovna Rada Ukrainy. 2020. “Narodni Deputaty Ukrainy.” http://w1.c1.rada.gov.ua/pls/site2/p_deputat_list. (Accessed July 5, 2020.)

Verner, Nelli. 2014. “Komandyr 'Azova’ podav dokumenty na reestratsiiu kandydatom u narodni deputaty.” LB.ua, September 23, 2014. http://lb.ua/society/2014/09/23/280282_kombat_azova_podal_dokumenti.html. (Accessed February 10, 2018.)

Viter, Marta. 2015. "Pozyvnyy Molfar: Pysmennyk na viini.” Ukrains'ka pravda, February 6, 2015. http://life.pravda.com.ua/ society/2015/02/6/188936. (Accessed February 8, 2018.)

VKontakte. 2015. “4 rota 'Sich’ polku 'Kyiv'.” VKontakte, https://vk.com/bsp_sich. (Accessed February 8, 2018.)

Vlashchenko, Nataliia. 2016a. "Semen Semenchenko: 'Ya dlya 90\% rodstvennikov - predatel,' eto stalo prichinoy smeny familii." 112.ua, May 12, 2016. https://web.archive.org/web/20170503105111/http://112.ua/interview/ya-dlya-90-rodstven nikov-predatel-eto-stalo-odnoy-iz-prichin-smeny-familii-310896.html. (Accessed May 12, 2021.)

Vlashchenko, Nataliia. 2016b. "Yuriy Bereza: Ya khotiv by, shchob viyna zakinchylasya, todi ya povernusya v sil's'ke hospodarstvo.” 112.ua, July 7, 2016. https://web.archive.org/web/20170131144223/https://ua.112.ua/interview/ya-khotivby-shchob-viina-zakinchylasia-todi-ia-povernusia-v-silske-hospodarstvo-323309.html. (Accessed May 12, 2021.)

VNO “Komitet vybortsiv Ukrainy.” 2015. “Osnovni vysnovky opytuvannia rehionalnykh ekspertiv KVU 'Pivroku do mistsevykh vyboriv novi hravtsi ta stari problem.” May 13, 2015. http://cvu.org.ua/nodes/view/type:news/slug:Pivroku_do_ miscevyh_vyboriv_novi_gravci_stari_problemy. (Accessed February 8, 2018.)

Volunteer.org. 2014. “Polk 'Azov' - polk patrul'noi sluzhby militsii osoblyvoho pryznachennia.” https://web.archive.org/web/ 20180823114210/www.volunteer.org.ua/about/azov/. (Accessed May 12, 2021.)

Volunteer.org. 2018. “Tsyvilnyy korpus Azov.” https://web.archive.org/web/20180212193424/http://www.volunteer.org.ua/ about/. (Accessed May 12, 2021.) 
Volyns'ki novyny. 2017. “'Heroi-deputat' chy vse zh taky samozvanets Ihor Lapin? Chastyna III.” Volyns'ki Novyny, March 30, 2017. https://www.volynnews.com/news/authority/heroy-deputat-chy-vse-zh-taky-samozvanets-ihor-lapin-chastynaiii/. (Accessed August 29, 2018.)

Vovnyanko, Dmytro. 2017. “'S’omky' vid 'Samopomochi.”' Tverezo.info, September 10, 2017. http://tverezo.info/post/22815. (Accessed February 13, 2018.)

Vseukrains'ke ob’ednannia “Svoboda.” 2015. "Ruslan Koshulyns'kyy, Oleksiy Kayda, Markiyan Lopachak vyrushayut' artylerystamy na front.” February 8, 2015. https://web.archive.org/web/20170919153726/http://svoboda-files.info/files/00001337_ hazeta_svoboda_nomer_292.pdf. (Accessed May 12, 2021.)

Wikipedia. 2018. “Mistsevi vybory v Ukraini 2015.” https://uk.wikipedia.org/wiki/Мiсцеві_вибори_в_Україні_2015. (Accessed February 9, 2018.)

Yarosh, Dmytro. 2014. "Ya by zaraz ne vidmovyvsia vid hroshei bud-iakoho oliharkha." Glavkom, July 28, 2014. http:// glavcom.ua/publications/125703-dmitro-jarosh-ja-bi-zaraz-ne-vidmovivsja-vid-groshej-bud-jakogo-oligarha.html. (Accessed February 8, 2018.)

Yarosh, Dmytro. 2016. "Ya nikoly ne buv radykalom." Ukrains'ka pravda, November 7, 2016. http://www.pravda.com.ua/ articles/2016/11/7/7125992/. (Accessed February 8, 2018.)

Yavir, Iryna. 2016. “Partiia dlia 'Azovu'” Politychna Krytyka, October 11. http://ukraine.politicalcritique.org/2016/10/11/ partiya-dlya-azovu/. (Accessed February 9, 2018.)

Yuliia Tymoshenko. 2018. “Batalion 'Bat'kivshchyna' otrymav cherhovu partiiu dopomohy.” Yuliia Tymoshenko, February 13, 2018. https://web.archive.org/web/20150514202208/http://www2.tymoshenko.ua/ruh-oporu/bataljon-batkivshhynaotrymav-chergovu-partiyu-dopomogy/. (Accessed May 12, 2021.)

Zhegulev, Il'ya. 2014. “'Privatbank': Milliarder Kolomoys'kiy vedot chastnuyu voynu za yedinstvo Ukrainy.” Forbes, May 27, 2014. http://www.forbes.ru/sobytiya/obshchestvo/258279-privattank-milliarder-kolomoiskii-vedet-chastnuyu-voinuza-edinstvo-ukra. (Accessed February 10, 2018.)

Zheliznyak, Oleksandr. 2017. "Andriy Teteruk: Onyshchenko vytratyv 30 milioniv dolariv, shchob znyshchyty Yatseniuka." Narodna pravda, September 13, 2017. https://narodna-pravda.ua/2017/09/13/andrij-teteruk-onyshhenko-vytratyv-30-mil joniv-dolariv-shhob-znyshhyty-yatsenyuka/. (Accessed February 13, 2018.)

Zhyrokhov, Mykhaylo. 2016. "Kirovohrads'kiy batalion 'Rukh oporu.”' CHELine, December 20, 2016. http://cheline.com.ua/ news/mens-club/kirovogradskij-bataljon-ruh-oporu-47885. (Accessed February 13, 2018.)

Zhytomyr.info. 2015. “U Zhytomyri nardep Kupriy rozpoviv pro ideolohiiu partii 'UKROP’ ta predstavyv holovu ii oblasnoho oseredku.” Zhytomyr.info, July 30, 2015. http://www.zhitomir.info/news_149270.html. (Accessed February 10, 2018.)

ZIK. 2017. "Semenchenko pro povernennia Saakashvili: U Lvovi my ochikuvaly sprob zahostrennia sytuatsii." September 22, 2017. https://web.archive.org/web/20190711155418/http://zik.ua/news/2017/09/22/semenchenko_pro_povernennya_ saakashvili_u_lvovi_my_ochikuvaly_sprob_1172895. (Accessed May 12, 2021.)

Zvarych, Roman. 2016. "Eks-ministr yustytsii pro khulihans'ke zhyttia v Niu-Iorku: My z bratom vybyvaly zuby.” 5 kanal, October 26, 2016. https://www.5.ua/interview/zvarych-129413.html. (Accessed July 6, 2020.)

\section{Interviews}

Baida, Stepan. 2017. Azov Battalion co-founder and National Corps representative. Interviewed by Andreas HeinemannGrüder, January 12. Kyiv.

Chalavan, Viktor. 2017. Former Interior Ministry official. Interviewed by Andreas Heinemann-Grüder, January 13. Kyiv.

Lapin, Ihor. 2018a. Former Aidar Battalion fighter and 2014-2019 Member of Parliament. Interviewed by Andreas Heinemann-Grüder and Andreas Umland, January 17. Kyiv.

Parasiuk, Volodymyr. 2018. Former Dnipro Battalion fighter and 2014-2019 Member of Parliament. Interviewed by Andreas Heinemann-Grüder and Andreas Umland, January 18. Kyiv.

Petrenko, Oleh. 2018. Former Azov Civil Corps activist and 2014-2019 Member of Parliament. Interviewed by Andreas Heinemann-Grüder and Andreas Umland, 17 January. Kyiv.

Semenchenko, Semen. 2018. Founder of the Donbas Battalion and 2014-2019 Member of Parliament. Interviewed by Andreas Heinemann-Grüder and Andreas Umland, January 19. Kyiv.

Skoropads'kyy, Artem. 2017. Press secretary of the Right Sector. Interviewed by Andreas Umland, February 5. Kyiv.

Syrotiuk, Yurii. 2017. Leading Svoboda member and 2012-2014 Member of Parliament. Interviewed by Andreas Umland, February 7. Kyiv.

Teteruk, Andriy. 2018. Co-founder of the Myrotvorets Battalion and 2014-2019 Member of Parliament. Interviewed by Andreas Heinemann-Grüder and Andreas Umland, 17 January. Kyiv.

Zvarych, Roman. 2018. Former Minister of Justice of Ukraine, 2014-2015 Azov Civil Corps activist and 2018-2020 Member of Parliament. Interviewed by Andreas Heinemann-Grüder and Andreas Umland, January 16. Kyiv.

Cite this article: Fedorenko, K. and Umland, A. 2022. Between Frontline and Parliament: Ukrainian Political Parties and Irregular Armed Groups in 2014-2019. Nationalities Papers 50: 237-261, doi:10.1017/nps.2021.20 